\title{
Melatonin as a Chemical Substance or as Phytomelatonin Rich-Extracts for Use as Plant Protector and/or Biostimulant in Accordance with EC Legislation
}

\author{
Marino B. Arnao *(1) and Josefa Hernández-Ruiz \\ Department of Plant Physiology, University of Murcia, 30100-Murcia, Spain; jhruiz@um.es \\ * Correspondence: marino@um.es; Tel.: +34 868887001
}

Received: 3 September 2019; Accepted: 19 September 2019; Published: 21 September 2019

check for updates

\begin{abstract}
Melatonin ( $N$-acetyl-5-methoxytryptamine) is a ubiquitous molecule present in animals and plants, and also in bacteria and fungi. In plants, it has an important regulatory and protective role in the face of different stress situations in which it can be involved, mainly due to its immobility. Both in the presence of biotic and abiotic stressors, melatonin exerts protective action in which, through significant changes in gene expression, it activates a stress tolerance response. Its anti-stress role, along with other outstanding functions, suggests its possible use in active agricultural management. This review establishes considerations that are necessary for its possible authorization. The particular characteristics of this substance and its categorization as plant biostimulant are discussed, and also the different legal aspects within the framework of the European Community. The advantages and disadvantages are also described of two of its possible applications, as a plant protector or biostimulant, in accordance with legal provisions.
\end{abstract}

Keywords: biostimulant; fertilizer; melatonin; phytomelatonin; plant protector; plant stress

\section{Introduction}

Melatonin ( $\mathrm{N}$-acetyl-5-methoxytryptamine) is a biogenic amine derived from the amino acid tryptophan, which was discovered in 1958 in the cow pineal gland by Lerner and cols. [1]. Two years later, it was detected in humans and its chemical structure was elucidated. This molecule, which was initially only related to changes in the structure of melanocytes in amphibians, fish and reptiles, was soon found to act as a neurohormone in mammals [2,3]. Since its discovery it has become one of the most researched molecules. In animals, it presents a multitude of physiological actions such as a role in the circadian rhythms of several molecules, and its influence on sleep-wake cycles, mood, motor activity and body temperature changes [4-7]. Its influence on food intake and its relationship with metabolic syndrome has also been demonstrated [8-10]. In other more specific situations such as the physiology of the retina, the immune system, sexual behavior and as an anti-cancer effector, melatonin also has a relevant role [11-15]. In addition, interesting and extensive reviews on the role of melatonin in animals and humans can be consulted [16-23].

In 1995, the presence of melatonin in plants was discovered [24-27]. During the following years there was much reluctance on the part of researchers to accept this, since some refused to believe that a neurohormone could be present in plants, and much less that it had any role in their physiology. A key piece was the elucidation of the melatonin biosynthesis route in plants, localized between the mitochondria, chloroplasts and cytoplasm of cells, and which has been studied with great accuracy by K. Back and J. Kong in rice and Arabidopsis plants [28-30]. However, it is now fully accepted that melatonin is present in all plant species and that it presents a panoply of interesting actions. Indeed, 
several studies have demonstrated its role in processes such as seed germination, growth and the development of seedlings, leaves and roots. It takes part in organogenesis processes such as rooting and fruiting, and in processes of leaf and fruit senescence. It acts as a protector of the photosynthetic and stomatic system, and as a regulator of various enzymes of the metabolism of carbohydrates, lipids, amino acids, nitrogen, sulfur and phosphorus. It also has a role in the secondary metabolism, enhancing the synthesis of flavonoids, anthocyanins, and carotenoids, among others. It regulates its own biosynthesis and that of several plant hormones such as auxin, abscisic acid, gibberellins, cytokinins, ethylene, polyamines, jasmonic acid and salicylic acid [31-39].

Of all the aspects investigated, its protective action against stress situations has been the most researched and about which most is known. Melatonin exerts a protective action, mediated by major changes in gene expression, both against abiotic (cold, heat, drought, waterlogging, salinity, alkalinity, acid rain, chemical contamination by heavy metals, UV radiation) and biotic (bacteria, fungi, virus) stressors. As a result, plants are more tolerant and/or resistant to the negative action of such stressors $[31,36,40-43]$ (see below). The term "biostimulant" was first proposed to denote "materials that, in minute quantities, promote plant growth" by Zhang and Schmidt (1997) [44]. Later, the definition was modified by Kaufman et al. (2007) as: "Biostimulants are materials, other than fertilisers, that promote plant growth when applied in low quantities" [45]. According Du Jardin (2015), the following definition is proposed: "A plant biostimulant is any substance or microorganism applied to plants with the aim to enhance nutrition efficiency, abiotic stress tolerance and/or crop quality traits, regardless of its nutrients content", and extended as "plant biostimulants also designate commercial products containing mixtures of such substances and/or microorganisms" [46]. Under the EC (European Community) regulation: "Plant biostimulants will be EC marked as fertilizing products stimulating plant nutrition processes independently of the products' nutrient content with the sole aim of improving one or more of the following characteristics of the plant and the plant rhizosphere or phyllosphere: Nutrient use efficiency, tolerance to abiotic stress, crop quality, availability of confined nutrients in the soil and rhizosphere, humification and degradation of organic compounds in the soil". Extensive revision works on this topic can be consulted $[47,48]$. The objective of this work is to provide sufficient data to establish the clear protective role of melatonin against adverse environmental situations, and to discuss the possible global use of melatonin as a biostimulant and/or bioprotective agent. Current legislation of the EC, is taken into account and the advantages and disadvantages of its use in plant crops destined for animal and human consumption are analyzed.

\section{Melatonin as a Regulator of Plant Stress Physiology}

Although there was much evidence in the 1990s that melatonin could exert some role as an antioxidant agent in animal cells and tissues, it was not until 2004 and 2006, in carrot cells and Chinese licorice (Glycyrrhiza uralensis Fisch.), that the possible protective role of melatonin in plants was suggested [49-51], although some curious and previous data existed [52]. The initial idea that melatonin in plants, as in animals, could play an important role as an antioxidant was taking shape and results in this regard became ever more plentiful [53-57]. In addition, studies on melatonin as a possible plant regulator were also progressing, especially since the initial studies of Arnao and cols. on the role of melatonin in plant growth and development, and the so-called auxin-like activity [58-64].

It was not until the publication of results on the action of melatonin on changes in gene expression that the extent and potential of melatonin as a regulatory agent of multiple physiological processes in plants became widely known [64-70]. Exceeding previous expectations, melatonin is capable of activating all known molecular stress mechanisms in plants. Thus, gene regulatory factors involved in the response to cold, high temperatures, salinity, drought, chemical toxicity, etc., and also biotic stress, are up-regulated by melatonin [31,38,40,41,43]. Melatonin also regulates the expression of multiple enzymes related to hormonal homeostasis, up-regulating or down-regulating the expression of genes that encode enzymes of the biosynthetic or catabolic pathways of plant hormones including indole-3-acetic acid (auxin), gibberellins such as gibberellin-4 (GA 4$)$, cytokinins, abscisic 
acid (ABA) and ethylene. It also others regulators such as salicylic acid (SA), jasmonic acid (JA) and polyamines [31-33,35,38,69,71-75]. In general, subjecting plants to a stressful situation-which leads to an increase in endogenous levels of melatonin —or treatment with exogenous melatonin, results in a stress tolerance response mediated by specific stress response factors and changes in the endogenous levels of plant hormones involved in the response [31-36,38,40-43,75-85]. In addition, the recent identification of a melatonin receptor in Arabidopsis thaliana has opened new expectations related to its role as a new plant hormone [86]. Figure 1 shows these aspects in a condensed form.

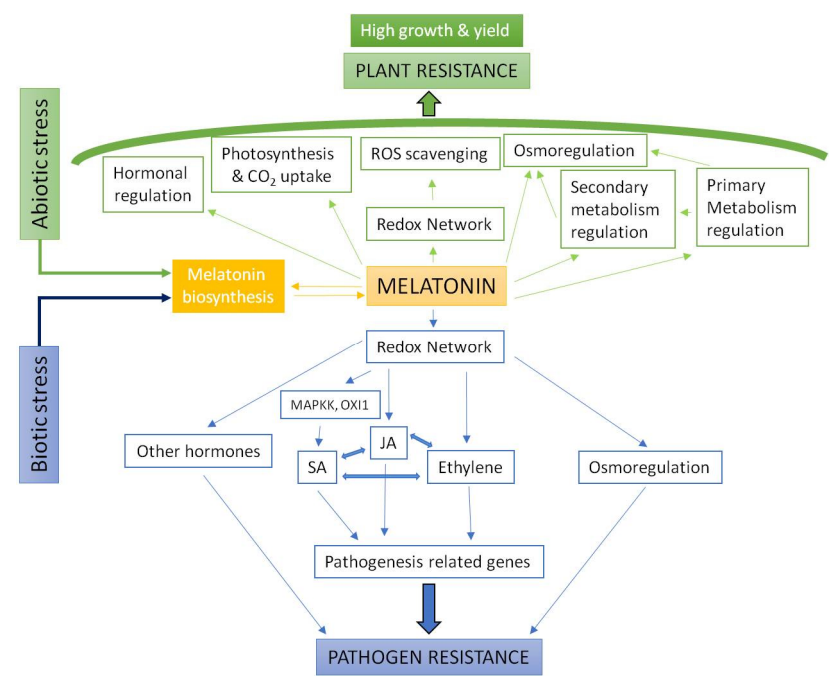

Figure 1. Model of redox network/melatonin action on abiotic and biotic stress responses.

\section{Beneficial Responses to Melatonin Treatments in Different Crops in Stress Situations}

Studies conducted with melatonin in plants under both abiotic and biotic stress are numerous. Table 1 compiles many of the studies with an agronomic interest since they deal primarily with crop species for human consumption. Table 1 presents studies classified by plant species, where there are many physiological aspects that are investigated in which melatonin exerts some generally beneficial action. These include seed germination, the growth and vegetative development of plants; photosynthesis, its pigments, photorespiration, stomatic conductance and water economy; the yields of seeds and fruits in adverse conditions; osmoregulation, ion exchange and adjustments in osmotic and hydric potentials, and the regulation of the different metabolisms of carbohydrates, lipids, nitrogen compounds, sulfur and phosphorus cycles. In regards to the secondary metabolism, melatonin induces the biosynthesis of flavonoids, anthocyanins and carotenoids, among others; in hormonal homeostasis, it intervenes in the regulation of all plant hormones and its own biosynthesis. It promotes the rooting process of primary, secondary and adventitious roots while during foliar senescence, melatonin regulates the expression of chlorophyll degradation-related and senescence-induced genes. In the postharvest control of fruits, melatonin increases the ethylene and lycopene content, and regulates many enzymes of the cell wall, ethylene biosynthesis, and primary and secondary metabolisms. It also helps preserve cut flowers; in fruiting it induces parthenocarpy. Finally, its role in bacterial, fungal and viral pathogenic infection should be emphasized, slowing damage and stimulating systemic acquired resistance (SAR) to favor crop health.

Obviously, all the above plant physiology aspects are of interest for application in plant production. Indeed, while many of the above studies were at a laboratory level, others have already been put into practice in crops with excellent results.

In general, exogenous melatonin applications are made through the root system, in irrigation water, or by spraying leaves. In the last case, no adjuvant is needed since melatonin is an amphipathic molecule that crosses biological membranes and the waxy cuticles. Melatonin is transported via the xylem from the roots to the rest of the organs of the plant quite effectively $[87,88]$. 
Table 1. Studies of different responses to melatonin treatments in different crop species in diverse stress situations.

\begin{tabular}{|c|c|c|c|c|}
\hline Plant Species & Stress Type & Melatonin Treatment $(\mu \mathrm{M})$ & Effects Observed & Reference \\
\hline \multirow[t]{3}{*}{ Alfalfa } & Waterlogging & 100 & $\begin{array}{c}\uparrow \text { tolerance, growth, photosynthesis, Chls, } \\
\text { polyamines, } \downarrow \text { electrolyte leakage, ROS, ethylene, } \\
\text { leaf senescence }\end{array}$ & [89] \\
\hline & Metal-Cd & $10-200$ & $\begin{array}{c}\uparrow \text { tolerance, growth, Cd transporters, } \downarrow \text { Cd in roots, } \\
\text { ROS }\end{array}$ & [90] \\
\hline & Oxidative & $1-100$ & $\uparrow$ lateral root formation, cell division & [91] \\
\hline \multirow[t]{8}{*}{ Apple } & Salinity & 0.1 & $\begin{array}{c}\uparrow \text { shoot height, leaf number, Chls, } \mathrm{K}^{+}, \downarrow \text { electrolyte } \\
\text { leakage, ROS }\end{array}$ & {$[92,93]$} \\
\hline & Drought & 100 & $\begin{array}{c}\uparrow \text { tolerance, re-open stomata, water in leaf, } \\
\text { photosynthesis, N uptake, } N \text { metabolism, growth, } \\
\downarrow \text { ABA activity, ROS, leaf senescence }\end{array}$ & {$[71,94-96]$} \\
\hline & Waterlogging & 200 & $\begin{array}{l}\downarrow \text { chlorosis, wilting of the seedlings, ROS, } \uparrow \\
\text { tolerance, photosynthesis }\end{array}$ & [97] \\
\hline & Alkaline & 5 & $\begin{array}{c}\uparrow \text { tolerance, root system, redox balance, } \\
\text { polyamines }\end{array}$ & [98] \\
\hline & Leaf-senescence & $10 \mathrm{mM}$ & $\begin{array}{l}\downarrow \text { senescence, ROS burst, } \uparrow \text { Chls, photosynthesis, } \\
\text { sucrose, starch, N }\end{array}$ & {$[67,99,100]$} \\
\hline & Diplocarpon mali & $50-500$ & $\begin{array}{c}\uparrow \text { resistance to fungal infection, } \downarrow \text { leaf lesions, cell } \\
\text { death, pathogen expansion }\end{array}$ & [101] \\
\hline & Apple Replant Disease-ARD & 200 & $\begin{array}{c}\uparrow \text { growth, photosynthesis, } \mathrm{K} \text { levels, soil microbial, } \\
\downarrow \text { ARD effects, ROS }\end{array}$ & [102] \\
\hline & Apple Stem Grooving Virus & 15 & $\begin{array}{c}\uparrow \text { shoot regrowth, } 95 \% \text { shoots virus-free, virus-free } \\
\text { area }\end{array}$ & [103] \\
\hline Apricot & - & $10 \mathrm{ppm}$ & $\begin{array}{l}\uparrow \text { leaf growth, photosynthesis, fruit yield, size and } \\
\text { retention, TA, TSS }\end{array}$ & [104] \\
\hline \multirow[t]{2}{*}{ Banana } & Post-harvest & $200-500$ & $\begin{array}{c}\uparrow \text { shelf life of fruits, } \downarrow \text { ethylene, ripening, quality } \\
\text { sharp changes }\end{array}$ & [105] \\
\hline & Anthracnose & $10 \mathrm{mM}$ & $\begin{array}{l}\uparrow \text { fruit resistance, banana shelf life, } \downarrow \text { anthracnose } \\
\text { disease }\end{array}$ & [106] \\
\hline \multirow[t]{2}{*}{ Barley } & Cold, drought & $1 \mathrm{mM}$ & $\begin{array}{l}\uparrow \text { photosynthesis efficiency, ABA, water content, } \\
\text { ROS }\end{array}$ & [72] \\
\hline & Leaf-senescence & $0.01-1$ & $\uparrow$ Chls, growth, $\downarrow$ senescence & {$[59,107]$} \\
\hline Bermudagrass & Cold, salt, drought & 20-100 & $\begin{array}{c}\uparrow \text { growth, osmoregulation, } \downarrow \text { ROS burst, cell } \\
\text { damage }\end{array}$ & {$[108,109]$} \\
\hline
\end{tabular}


Table 1. Cont

\begin{tabular}{|c|c|c|c|c|}
\hline Plant Species & Stress Type & Melatonin Treatment $(\mu \mathrm{M})$ & Effects Observed & Reference \\
\hline Broccoli & - & $60 \mathrm{ppm}$ & $\begin{array}{l}\text { } \text { growth, photosynthetic attributes: LAI, NAR, } \\
\text { AGR, CGR, Chls, carotenoids }\end{array}$ & [110] \\
\hline \multirow[t]{2}{*}{ Cabbage } & Metal-Cu & $1-100$ & $\uparrow$ germination, growth, $\downarrow$ membrane peroxidation & [111] \\
\hline & - & $100-1000$ & $\begin{array}{c}\uparrow \text { growth, anthocyanins, osmoregulation, redox } \\
\text { balance, } \downarrow \text { ABA, senescence factors, Chls } \\
\text { degradation }\end{array}$ & {$[112,113]$} \\
\hline \multirow[t]{2}{*}{ Cassava } & - & 100 & $\begin{array}{l}\downarrow R O S \text {, postharvest deterioration, starch } \\
\text { degradation }\end{array}$ & [114] \\
\hline & Xam bacterial bligh & & $\begin{array}{c}\uparrow \text { disease resistance, } \downarrow \text { bacterial propagation in } \\
\text { leaves }\end{array}$ & [115] \\
\hline \multirow[t]{3}{*}{ Cherry sweet } & Rootstocks & $0.5-5$ & $\begin{array}{c}\uparrow \text { number of roots, length, } \% \text { rooting in } 3 \text { cherry } \\
\text { rootstocks }\end{array}$ & {$[116,117]$} \\
\hline & & & $\begin{array}{l}\uparrow \text { photosynthetic pigments, biomass, total } \\
\text { carbohydrates and proline }\end{array}$ & \\
\hline & Orchard trees & 10 & $\downarrow$ sweet cherries ripening, anthocyanins & [118] \\
\hline Citrus & Salinity & 1 & $\begin{array}{c}\uparrow \text { osmoregulation, Chls, } \downarrow \text { ROS burst, membrane } \\
\text { peroxidation }\end{array}$ & [119] \\
\hline Coffee & Drought & 300 & $\begin{array}{c}\uparrow \text { tolerance, root system, photosynthesis, gas } \\
\text { exchange, } \mathrm{CO}_{2} \text { fixation, Chls, ASA-GSH cycle, } \downarrow \\
\text { ROS, MDA }\end{array}$ & [120] \\
\hline Cotton & - & 20 & $\begin{array}{c}\uparrow \text { germination, growth, antioxidant enzymes, } \mathrm{GA}_{3}, \\
\qquad \text { ROS, MDA, ABA }\end{array}$ & [121] \\
\hline \multirow[t]{7}{*}{ Cucumber } & Cold & $25-500 \mathrm{mM}$ & $\uparrow$ germination, $\downarrow$ ROS, membrane peroxidation & [122] \\
\hline & Cold & $50-500$ & $\uparrow \mathrm{GSH}$ pool, $\downarrow$ ROS & [123] \\
\hline & Cold & 200 & $\begin{array}{l}\uparrow \text { tolerance, photosynthesis, polyamines, ABA, } \\
\text { GSH-ASA cycle, } \downarrow \text { electrolyte leakage, ROS, }\end{array}$ & {$[124,125]$} \\
\hline & Heat & 100 & $\begin{array}{c}\uparrow \text { tolerance, } \mathrm{N} \text { metabol., nitrate, } \downarrow \text { damage, } \\
\text { ammonium }\end{array}$ & [126] \\
\hline & $\mathrm{N}$-excess & 100 & $\begin{array}{c}\uparrow \text { tolerance, growth, NPK balance, Ca, } \downarrow \text { damage, } \\
\text { nitrate, ammonium }\end{array}$ & [127] \\
\hline & Salinity & 1 & $\begin{array}{c}\uparrow \text { germination, } \mathrm{GA}_{4}, \downarrow \text { ROS, membrane } \\
\text { peroxidation, ABA }\end{array}$ & [69] \\
\hline & & $50-150$ & $\begin{array}{c}\uparrow \text { tolerance, Chls, photosynthesis, GSH-ASA cycle, } \\
\downarrow \text { ROS }\end{array}$ & [128] \\
\hline
\end{tabular}


Table 1. Cont

\begin{tabular}{|c|c|c|c|c|}
\hline Plant Species & Stress Type & Melatonin Treatment $(\mu \mathrm{M})$ & Effects Observed & Reference \\
\hline & & 1 & $\begin{array}{l}\uparrow \text { germination, protein biosynthesis, lipid and } \\
\text { carbohydrate metabol., TCA, ATP }\end{array}$ & [129] \\
\hline & Drought & 100 & $\uparrow$ germination, root growth & [130] \\
\hline & Oxidative & 50 & $\begin{array}{c}\uparrow \text { systemic antioxidant defence, GSH, } \\
\text { photosynthesis, } \downarrow \text { ROS }\end{array}$ & [131] \\
\hline & Metal-Cu & 0.01 & $\begin{array}{c}\uparrow \text { tolerance, growth, Cu-sequestration, TCA, ATP, } \\
\text { GSH, } \downarrow \text { ROS }\end{array}$ & [132] \\
\hline & Cinnamic acid & 100 & $\begin{array}{l}\uparrow \text { tolerance, growth, water and nutrient balance, } \\
\text { hormonal balance }\end{array}$ & [133] \\
\hline Faba bean & Salinity & $100-500$ & $\begin{array}{l}\text { 个 plant height, RWC, photosynthetic pigments, } \\
\text { osmolites, phenolic }\end{array}$ & [134] \\
\hline \multirow[t]{4}{*}{ Grape } & Drought & $0.05-0.2$ & $\begin{array}{l}\uparrow \text { seedling growth, osmoregulation, } \\
\text { photosynthesis, } \downarrow \text { ROS burst }\end{array}$ & [135] \\
\hline & Salinity-Rhizobacteria & - & $\begin{array}{l}\uparrow \text { root growth, RWC, melatonin in roots, } \\
\text { colonization, } \downarrow \text { damage, ROS }\end{array}$ & [136] \\
\hline & Berry ripening & 100 & $\begin{array}{l}\uparrow \text { anthocyanins, phenols, flavonoids, } \\
\text { proanthocyanidins, resveratrol, } \downarrow \text { ROS }\end{array}$ & {$[137,138]$} \\
\hline & Berry/Wine & 430 & $\begin{array}{l}\uparrow \text { size- and ripening-berries, fruity-, spicy- and } \\
\text { sweet-wine }\end{array}$ & [139] \\
\hline \multirow[t]{2}{*}{ Kiwifruit } & Drought & 50-200 & $\begin{array}{c}\uparrow \text { tolerance, photosynthesis, } \mathrm{CO}_{2} \text { fixation, growth, } \\
\text { biomass, roots, osmoregulation, flavonoids } \downarrow \text { lipid } \\
\text { peroxidation, carotenoid degradation }\end{array}$ & {$[140,141]$} \\
\hline & Heat & 200 & $\begin{array}{l}\uparrow \text { tolerance, ASA, proline, antioxidant enzymes, } \downarrow \\
\text { heat damage, ROS }\end{array}$ & [142] \\
\hline Leek & Cold, heat & 5 & $\uparrow$ tolerance, germination, growth & [143] \\
\hline Lychee & Post-harvest & 400 & $\begin{array}{l}\uparrow \text { redox balance, antioxidant enzymes, } \downarrow \text { pericarp } \\
\text { browning, discoloration, ROS, membrane leakage, } \\
\text { loss of phenolics, flavonoids and anthocyanins }\end{array}$ & [144] \\
\hline Lupin & Several stress & - & $\begin{array}{l}\uparrow \text { germination, growth, rooting, redox balance, } \downarrow \\
\text { ROS, foliar senescence }\end{array}$ & {$[58,60,62,145]$} \\
\hline \multirow[t]{2}{*}{ Maize } & Salinity, heat & 100 & $\begin{array}{c}\uparrow \text { photosynthesis, antioxidant enzymes, } \downarrow \text { ROS, } \\
\text { electrolyte leakage }\end{array}$ & {$[146,147]$} \\
\hline & - & $10-1000$ & $\begin{array}{l}\uparrow \text { root and stem growth, plant height, leaf surface } \\
\text { area, protein, carbohydrates, Chls }\end{array}$ & [148] \\
\hline
\end{tabular}


Table 1. Cont.

\begin{tabular}{|c|c|c|c|c|}
\hline Plant Species & Stress Type & Melatonin Treatment $(\mu \mathrm{M})$ & Effects Observed & Reference \\
\hline & Drought & 100 & $\begin{array}{c}\uparrow \text { tolerance, growth, photosynthesis, stoma } \\
\text { conductance, transpiration, RWC, antiox enzymes, } \\
\downarrow \text { ROS, MDA }\end{array}$ & [149-151] \\
\hline & Heat & $10-90$ & $\begin{array}{c}\uparrow \text { tolerance, antioxidant enzymes, osmoregulation, } \\
\downarrow \text { ROS, MDA, electrolyte leakage }\end{array}$ & [152] \\
\hline & Metal-Pb & $50-100$ & $\begin{array}{c}\uparrow \text { tolerance, growth, photosynthesis, Chls, RWC, K, } \\
\text { Ca levels, } \downarrow \text { ROS, MDA }\end{array}$ & [153] \\
\hline & - & 10 & $\begin{array}{c}\uparrow \text { sugar metabolism, photosynthesis, sucrose } \\
\text { phloem loading }\end{array}$ & [154] \\
\hline & - & $50-500$ & $\begin{array}{l}\text { protein synthesis, folding, destination and storage, } \\
\text { defence, anti-stresses and detoxifying proteins }\end{array}$ & [155] \\
\hline & Aging seeds & & $\begin{array}{c}\uparrow \text { viability, growth, antioxidant enzymes, } \\
\text { carbohydrate-, secondary-, and amino acid } \\
\text { metabol., } \downarrow \text { ROS, MDA }\end{array}$ & [156] \\
\hline Melissa (lemon balm) & Metal-Zn-Cd & 1000 & $\uparrow$ tolerance, growth, antioxidant enzymes & [157] \\
\hline Mung bean & Cold & 20 & $\begin{array}{l}\uparrow \text { tolerance, growth, plastids, } \downarrow \text { ROS, lipid } \\
\text { peroxidation }\end{array}$ & [158] \\
\hline Oat & Salinity, drought & $50-100$ & $\begin{array}{c}\uparrow \text { tolerance, growth, Chls, proline, antioxidant } \\
\text { enzymes, } \downarrow \text { ROS, MDA }\end{array}$ & {$[59,159,160]$} \\
\hline Onion & Cold, heat & 5 & $\uparrow$ tolerance, germination, growth & [143] \\
\hline \multirow[t]{2}{*}{ Peach (fruit) } & Cold & $50-200$ & $\begin{array}{l}\uparrow \text { juice, TSS, polyamines, GABA, proline, } \downarrow \text { chilling } \\
\text { injury, ROS }\end{array}$ & [161] \\
\hline & Post-harvest & 100 & $\begin{array}{l}\uparrow \text { firmness, TSS. ASA, } \downarrow \text { weight loss, decay } \\
\text { incidence, respiration rate, }\end{array}$ & [162] \\
\hline \multirow[t]{2}{*}{ Pear (tree) } & - & 100 & $\begin{array}{l}\uparrow \text { photosynthesis, fruit size, TSS, sucrose, sorbitol, } \\
\text { starch }\end{array}$ & [163] \\
\hline & Parthenocarpy & 100 & $\begin{array}{l}\uparrow \text { parthenocarpy with expansion, division } \\
\text { mesocarp cells, unviable seeds, GAs }\end{array}$ & [73] \\
\hline Pear (fruit) & Post-harvest & 100 & $\begin{array}{l}\uparrow \text { firmness, commercial value, } \downarrow \text { weight loss, } \\
\text { ethylene, softening, core browning }\end{array}$ & {$[164,165]$} \\
\hline \multirow[t]{2}{*}{ Pepper } & Salinity, Fe-low & 100 & $\begin{array}{c}\uparrow \text { growth, Chls, photosynthesis, fruit yield, Fe, K } \\
\text { uptake, antioxidant enzymes }\end{array}$ & [166] \\
\hline & Cold & $1-5$ & $\begin{array}{c}\uparrow \text { germination, growth, antioxidant enzymes, } \downarrow \\
\text { ROS, MDA }\end{array}$ & [167] \\
\hline
\end{tabular}


Table 1. Cont

\begin{tabular}{|c|c|c|c|c|}
\hline Plant Species & Stress Type & Melatonin Treatment $(\mu \mathrm{M})$ & Effects Observed & Reference \\
\hline & Boron-high & 1 & $\begin{array}{l}\uparrow \text { tolerance, growth, photosynthesis, } \downarrow \text { B in leaf and } \\
\text { fruit, toxicity }\end{array}$ & [168] \\
\hline \multirow[t]{2}{*}{ Pea } & Oxidative & $50-200$ & $\begin{array}{c}\uparrow \text { photosynthesis efficiency, pigments, water } \\
\text { content, } \downarrow \text { ROS }\end{array}$ & {$[169,170]$} \\
\hline & Metal-Cu & 5 & $\uparrow$ plant survival & [171] \\
\hline Plum (fruit) & Cold & $1-1000$ & $\begin{array}{l}\uparrow \text { firmness, postharvest life, ASA, phenols, } \\
\text { antioxidant activity, } \downarrow \text { weight loss }\end{array}$ & [172] \\
\hline Pomegranate & Cold & 100 & $\begin{array}{c}\uparrow \text { tolerance, antioxidant enzymes, membrane } \\
\text { integrity, phenols, } \downarrow \text { ROS }\end{array}$ & [173] \\
\hline Poplar & Oxidative & & $\begin{array}{c}\uparrow \text { redox balance, proline, } \downarrow \text { ROS, MDA, membrane } \\
\text { damage, electrolyte leakage }\end{array}$ & {$[174]$} \\
\hline \multirow[t]{2}{*}{ Potato } & Salinity & $0.1-200$ & $\begin{array}{c}\uparrow \text { tolerance, } \mathrm{K}^{+} / \mathrm{Na}^{+} \text {homeostasis, ATPase, } \\
\text { triacylglycerol breakdown, fatty acid } \beta \text {-oxidation, } \\
\text { energy turnover }\end{array}$ & [175] \\
\hline & $\begin{array}{l}\text { Phytophthora infestans } \\
\text { (potato late blight) }\end{array}$ & $1-10 \mathrm{mM}$ & $\begin{array}{l}\uparrow \text { plant innate immunity, fungicide resistance and } \\
\text { virulence, synergistic anti-fungal effects of } \\
\text { melatonin with fungicides }\end{array}$ & [176] \\
\hline Radish & Heat & $50-300$ & $\begin{array}{l}\uparrow \text { biomass, quality, antioxidant enzymes, Chls, } \\
\text { hormone contents }\end{array}$ & [177] \\
\hline \multirow[t]{2}{*}{ Rapeseed } & Salinity & $0.01-100$ & $\begin{array}{l}\uparrow \text { tolerance, redox balance, ion homeostasis, } \downarrow \text { ROS, } \\
\text { MDA }\end{array}$ & [178] \\
\hline & Drought & 500 & $\begin{array}{c}\uparrow \text { tolerance, germination, Chls, stoma size, } \\
\text { osmoregulation, antioxidant enzymes, } \downarrow \text { ROS, } \\
\text { MDA }\end{array}$ & [179] \\
\hline \multirow[t]{6}{*}{ Rice } & Cold & $20-100$ & $\begin{array}{c}\uparrow \text { tolerance, growth, photosynthesis, redox balance, } \\
\downarrow \text { ROS }\end{array}$ & [180] \\
\hline & Salinity & $10-20$ & $\uparrow$ Chls, $\downarrow$ senescence, ROS, cell death & [181] \\
\hline & Metal-Cd & & $\begin{array}{l}\uparrow \text { tolerance, growth, photosynthesis, redox balance, } \\
\text { panicle number, grain yield }\end{array}$ & {$[182,183]$} \\
\hline & Bacterial blight & 200 & $\downarrow$ bacterial proliferation, motility & [184] \\
\hline & Salt, cold, Blast fungus & - & $\begin{array}{l}\uparrow \text { tolerance, melatonin induction, hormones, } \downarrow \\
\text { fungi proliferation }\end{array}$ & [185] \\
\hline & - & $0.5-1$ & $\begin{array}{c}\uparrow \text { seminal roots, lateral roots, root growth, root } \\
\text { biomass }\end{array}$ & [186] \\
\hline
\end{tabular}


Table 1. Cont

\begin{tabular}{|c|c|c|c|c|}
\hline Plant Species & Stress Type & Melatonin Treatment $(\mu \mathrm{M})$ & Effects Observed & Reference \\
\hline & Soil & $10-50$ & $\begin{array}{c}\uparrow \text { number of lateral roots, root growth, shaping } \\
\text { root architecture }\end{array}$ & [187] \\
\hline \multirow[t]{3}{*}{ Soybean } & Salinity, drought & $50-100$ & $\begin{array}{l}\uparrow \text { tolerance, seedling growth, leaf size, biomass, } \\
\text { seed yield }\end{array}$ & [188] \\
\hline & Drought & 100 & $\begin{array}{c}\uparrow \mathrm{RWC}, \text { Chls, photosynthetic gas-exchange } \\
\text { parameters, osmoregulation, antioxidant enzymes, } \\
\text { and seed growth-related indicators }\end{array}$ & [189] \\
\hline & Metal-Al & $0.1-1$ & $\begin{array}{c}\uparrow \text { tolerance, root growth, antioxidant enzymes, } \\
\text { osmoregulation, } \downarrow \text { ROS, }\end{array}$ & [190] \\
\hline Spinach & Boron & $100-300$ & $\begin{array}{c}\uparrow \text { tolerance, growth, photosynthesis, } \mathrm{RWC}, \mathrm{CO}_{2} \\
\text { uptake, sugars, carotenoids, redox balance, } \downarrow \text { ROS, } \\
\text { MDA }\end{array}$ & [191] \\
\hline \multirow[t]{2}{*}{ Strawberry } & Post-harvest & 100 & $\begin{array}{l}\uparrow \text { nutritional quality, antioxidant enzymes, } \\
\text { anthocyanins, phenols, GABA, ATP } \downarrow \text { fungal decay }\end{array}$ & [192] \\
\hline & Post-harvest & $0.1-1$ & $\begin{array}{c}\uparrow \text { color, firmness, TSS, ASA, flavonoids, } \downarrow \text { weight } \\
\text { loss, senescence, ROS, MDA }\end{array}$ & [193] \\
\hline Sunflower & Salinity & 15 & $\begin{array}{l}\uparrow \text { root, hypocotyl growth, antioxidant potential, } \\
\text { antioxidant enzymes, GSH }\end{array}$ & [194-196] \\
\hline Tea plant & Salinity, cold, drought & 100 & $\begin{array}{c}\uparrow \text { photosynthesis, GSH, ASA, antioxidant enzymes, } \\
\downarrow \text { ROS, MDA }\end{array}$ & {$[197,198]$} \\
\hline Tobacco & Tobacco mosaic virus & 100 & $\begin{array}{c}\uparrow \text { tolerance, } \downarrow \text { virus proliferation, virus-RNA, viral } \\
\text { disease }\end{array}$ & [199] \\
\hline \multirow[t]{6}{*}{ Tomato } & Salinity & $50-150$ & $\begin{array}{c}\uparrow \text { photosynthesis, PSII efficiency, D1 protein } \\
\text { turnover, } \downarrow \text { ROS burst }\end{array}$ & [200] \\
\hline & Salinity & $20-50$ & $\begin{array}{l}\uparrow \text { growth, photosynthesis, Rubisco, proline, } \\
\text { C-metabol., ASA-GSH cycle, } \downarrow \text { ROS, MDA }\end{array}$ & [201] \\
\hline & Salinity & 150 & $\begin{array}{c}\uparrow \text { tolerance, photosynthesis, PSII repair, ASA-GSH } \\
\text { cycle, } \downarrow \text { ROS }\end{array}$ & [202] \\
\hline & Cold & 100 & $\begin{array}{l}\text { T antioxidant enzymes, GSA, ASA, } \mathrm{CO}_{2} \text { uptake, } \\
\text { sucrose, proline, Calvin cycle, polyamines, } \downarrow \text { ROS, } \\
\text { MDA, electrolyte leakage }\end{array}$ & [203] \\
\hline & Cold & 100 & $\begin{array}{c}\uparrow \text { tolerance, growth, VAZ cycle, photosynthesis, } \\
\text { photosystem efficiency, } \downarrow \text { ROS, MDA, } \\
\text { photoinhibition }\end{array}$ & [204] \\
\hline & Cold-fruit & 100 & $\begin{array}{c}\uparrow \text { tolerance, proline, polyamines, membrane } \\
\text { integrity }\end{array}$ & [205] \\
\hline
\end{tabular}


Table 1. Cont

\begin{tabular}{|c|c|c|c|c|}
\hline Plant Species & Stress Type & Melatonin Treatment $(\mu \mathrm{M})$ & Effects Observed & Reference \\
\hline & Heat & 10 & $\uparrow$ thermotolerance and cell protection & {$[206,207]$} \\
\hline & Heat-pollen & 20 & $\begin{array}{c}\uparrow \text { thermotolerance, polen germination, antioxidant } \\
\text { enzymes, reproductive development }\end{array}$ & [208] \\
\hline & Metal-Cd & $25-500$ & $\uparrow \mathrm{Cd}$ tolerance, phytochelatins, ATPase activity & [209] \\
\hline & Metal-Cd & - & $\begin{array}{l}\uparrow \mathrm{Cd} \text { tolerance, heat-shock factor A1a induction by } \\
\text { melatonin }\end{array}$ & [210] \\
\hline & Metal-Cd-Se & - & $\begin{array}{l}\uparrow \text { growth, photosynthesis, electrolyte leakage, } \\
\text { phytochelatins, GSH, } \downarrow \text { ROS, Cd leaf, }\end{array}$ & [211] \\
\hline & Alkalinity & $0.25-1$ & $\begin{array}{c}\text { seedling growth, photosynthesis, ion homeostasis, } \\
\text { burst }\end{array}$ & [212] \\
\hline & Acid rain & 100 & $\begin{array}{c}\uparrow \text { tolerance, growth, chloroplast integrity, } \\
\text { photosynthesis, antioxidant enzymes, } \downarrow \text { ROS, MDA }\end{array}$ & [213] \\
\hline & Drought & 100 & 个 tolerance, waxes-cutin leaf, RWC, Chls, & [214] \\
\hline & Drought & 100 & $\begin{array}{l}\uparrow \text { tolerance, Chls, antioxidant enzymes, } \\
\text { p-coumaric acid, } \downarrow \text { ROS, MDA }\end{array}$ & [215] \\
\hline & S-low & 100 & $\begin{array}{l}\uparrow S \text { uptake, assimilation, transport and metabolism, } \\
\text { peroxiredoxins, redox homeostasis, } \downarrow \text { ROS, DNA } \\
\text { damage }\end{array}$ & [216] \\
\hline & Rooting & 50 & $\begin{array}{l}\uparrow \text { adventitious root formation, auxin, auxin } \\
\text { transport and signal transduction }\end{array}$ & [217] \\
\hline & On vine-ripening & & $\begin{array}{c}\uparrow \text { fruit yield and quality, ASA, citric acid, lycopene, } \\
\text { TSS, Ca, } \mathrm{P} \downarrow N, \mathrm{Mg}, \mathrm{Cu}, \mathrm{Zn}, \mathrm{Fe}, \mathrm{Mn},\end{array}$ & [218] \\
\hline & Post-harvest & 50 & $\begin{array}{l}\text { ^ fruit ripening, fruit quality, colour, carotenoids, } \\
\text { polygalacturonase and related, biosynthesis, } \\
\text { perception and signalling of ethylene, } \\
\text { anthocyanins, } \downarrow \text { weight loss }\end{array}$ & {$[74,219]$} \\
\hline & Mosaic virus & 100 & $\begin{array}{c}\uparrow \text { tolerance, } \downarrow \text { virus proliferation, virus-RNA, viral } \\
\text { disease }\end{array}$ & [199] \\
\hline Valerian & Metal-Zn-Cd & 1000 & $\uparrow$ tolerance, growth, antioxidant enzymes & [157] \\
\hline \multirow[t]{2}{*}{ Watermelon } & Cold & 150 & $\uparrow$ photosynthesis, $\downarrow$ cold-related microRNA & [220] \\
\hline & Salinity & $50-500$ & $\begin{array}{l}\uparrow \text { tolerance, growth, photosynthesis, antioxidant } \\
\text { enzymes, GSH, ASA, } \downarrow \text { ROS, MDA }\end{array}$ & [221] \\
\hline
\end{tabular}


Table 1. Cont

\begin{tabular}{|c|c|c|c|c|}
\hline Plant Species & Stress Type & Melatonin Treatment $(\mu \mathrm{M})$ & Effects Observed & Reference \\
\hline & Metal-V & 0.1 & $\begin{array}{l}\uparrow \text { tolerance, growth, photosynthesis, antioxidant } \\
\text { enzymes, } \downarrow \text { V level, V transport, ROS, MDA }\end{array}$ & [222] \\
\hline \multirow[t]{10}{*}{ Wheat } & Cold & 1000 & $\uparrow$ redox balance, Chls, osmoregulation, $\downarrow$ ROS & [223] \\
\hline & Cold & 1000 & $\begin{array}{l}\uparrow \text { tolerance, growth, Chls, photosynthesis, } \mathrm{CO}_{2} \\
\text { uptake, grain filled }\end{array}$ & [224] \\
\hline & Cold & 1000 & $\begin{array}{l}\uparrow \text { photosynthesis, stomatal conductance, } \\
\text { antioxidant enzymes, membrane stability }\end{array}$ & [225] \\
\hline & Salinity & 1 & $\begin{array}{c}\uparrow \text { tolerance, growth, photosynthesis, IAA, } \\
\text { polyamines, } \downarrow \text { ROS }\end{array}$ & [226] \\
\hline & Salinity & $50-500$ & $\begin{array}{c}\uparrow \text { growth, yield, antioxidant enzymes, } \downarrow \text { ROS, } \\
\text { MDA }\end{array}$ & [227] \\
\hline & Drought & 500 & $\begin{array}{l}\uparrow \text { tolerance, RWC, photosynthesis, antioxidant } \\
\text { enzymes, ASA, GSH, } \downarrow \text { ROS, membrane damage }\end{array}$ & [228] \\
\hline & Metal-Cd & 100 & $\begin{array}{l}\uparrow \text { tolerance, antioxidant enzymes, ASA, GSH, } \downarrow \\
\text { ROS }\end{array}$ & [229] \\
\hline & Metal-Cd & $50-100$ & $\begin{array}{l}\uparrow \text { tolerance, growth, Chls, photosynthesis, RWC, } \\
\text { Ca, K, antioxidant enzymes, } \downarrow \text { ROS, MDA, Cd }\end{array}$ & [230] \\
\hline & Metal-Zn & 1000 & $\uparrow$ tolerance, Chls, photosynthesis, Rubisco, ATPase & [231] \\
\hline & N-low & 1 & $\begin{array}{l}\uparrow \mathrm{N} \text { and nitrate, } \mathrm{N} \text { absorption, } \mathrm{N} \text { metabolism, } \\
\text { growth, yield, in shoots and roots }\end{array}$ & [232] \\
\hline
\end{tabular}

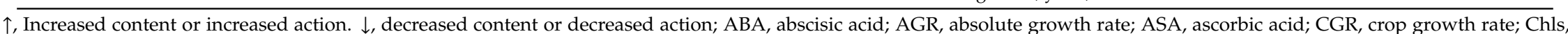
chlorophylls; CMC, component materials categories of fertilizers; EC, European Community; ECHA, European Chemical Agency; EU, European Union; GA, gibberellin-4; GABA, $\gamma$-aminobutyric acid; GSH, glutathione; JA, Jasmonic acid; LAI, leaf area index; MDA, malondialdehyde; MAPKK, mitogen-activated protein kinase cascade; NAR, net assimilation rate; OXI1, oxidative signal-inducible1 kinases; PFC, product function categories of fertilizers; ROS, reactive oxygen species; RWC, relative water content; SA, salicylic acid; SAR, systemic acquired resistance; TA, total valuable acidity; TCA, Krebs cycle; TSS, total solid soluble. 


\section{Melatonin in the Health and Environment of EC}

In accordance with the Classification, Labelling and Packaging (CLP, EC-No 1272/2008) regulation, which is based on the United Nations' Globally Harmonized System, which has a purpose to ensure a high level of protection of health and the environment, as well as the free movement of substances, mixtures and articles, the European Chemical Agency (ECHA) classified melatonin (EC No. 200-797-7 (CAS 73-31-4), N-(2-(5-methoxyindol-3-yl)-ethyl)-acetamide), as a non-hazardous substance in terms of physical and chemical hazards. With respect to human health, it is classified as a non-hazardous substance in the oral, dermal, inhalation and irritation categories, and in regards to mutagenicity and carcinogenicity. However, melatonin is classified as a health hazard substance (code H-361) in terms of reproductive toxicity because it is suspected of damaging fertility or an unborn child. This classification reflects one of its multiple functions as an animal hormone, in which its participation in the modulation of sexual behavior in mammals has been demonstrated, and also, it is believed, the same of fertility $[233,234]$. In fact, it is usually applied to sheep as a hormonal regulator of sexual zeal to homogenize the reproductive process in ovine, with demonstrated higher conception and pregnancy rates when applied [235]. Nevertheless, melatonin is classified as non-hazardous in terms of its possible damage to the environment and atmosphere.

\section{Melatonin as an Active Substance or as a Plant Biostimulator/Protector in Crops: Concepts and Legal Considerations in EC}

After many changes and adaptations, the EC finally seems to have established its policy regarding the authorization, classification, use, distribution, importation, management, etc., of plant protectors and fertilizers, in an attempt to improve agricultural production, while minimizing risks and hazards for humans, animals and the environment. In order to establish the minimum basis for the possible use of melatonin in plant production and post-harvest application, several requirements regarding its human consumption must be taken into account:

(i) Melatonin is a highly studied substance that has given rise to abundant physicochemical and biological data; (ii) there are numerous studies in animals and humans regarding its beneficial effects on health, in aspects as diverse as neurodegenerative, immunological, liver, renal, heart, skin and gastrointestinal diseases, in addition to osteopathy, retinopathy, etc. It also helps in the treatment of various cancers, particularly, chemical and radiological therapies; (iii) in regards to melatonin for human consumption, although it is classified as a drug in the EC, there are some cases in which it does not need a medical prescription, such as those where the amount of melatonin is less than $1 \mathrm{mg}$. Generally, these are used for jet-lag and sleep disorders. In many other countries (e.g., USA, Canada) melatonin is not treated as a drug, but as a food supplement; (iv) in no case has melatonin been declared as toxic, even at the intake of $1 \mathrm{~g}$ /day. Only some slight side effects such as migraine and headache have been described.

The possible use of melatonin in plant production involves particular aspects such as: (i) Melatonin is a molecule that exists in all living things, from bacteria to humans, but also in plants, algae, fungi, etc.; (ii) its action in animals and humans is well known since it has been investigated for many years. In plants, although many physiological effects of melatonin are known, new data are being acquired every day; (iii) in all cases, only positive effects have been described, all beneficial for the development of plants (the same can be said for animals); (iv) little information is available on its effect on bacteria and fungi, especially those that are part of the soil microbiota (rhizosphere); (v) there are also few or no data on its effect on the environment, in particular on agricultural and aquatic fauna; (vi) the levels of melatonin described in plants, and which appear to be effective in pharmacological treatments known to date, are much higher than those described in animals or humans, which may be a cause for caution.

Council Directive 91/414/EEC of 15 July, 1991 concerning the marketing of plant protection products provides rules governing plant protection products and the active substances contained in those products. This old directive has been replaced by two more current ones that are as follows: 
- Regulation \#1. Regulation EC 1107/2009 of the European Parliament and of the Council of 21 October 2009 concerning the placing of plant protection products on the market and repealing council directives 79/117/EEC and 91/414/EEC, and;

- Regulation \#2. Regulation EU 2019/1009 of the European Parliament and of the Council of 5 June 2019 laying down rules on the making available on the market of EU fertilizing products and amending Regulations (EC) No. 1069/2009 and (EC) No. 1107/2009 and repealing Regulation (EC) No 2003/2003.

If we review the actions confirmed so far for melatonin in plants, we find that melatonin exerts a clear action as a plant protector in situations of biotic stress against bacterial, fungal and viral diseases (Regulation \#2), but it can also be used as an agent against situations of abiotic stress (Regulation \#1). Thus, Regulation \#2 says in point 22:

"Certain substances, mixtures and micro-organisms, referred to as plant biostimulants, are not as such inputs of nutrients, but nevertheless stimulate plants' natural nutrition processes. Where such products aim solely at improving the plants' nutrient use efficiency, tolerance to abiotic stress, quality traits or increasing the availability of confined nutrients in the soil or rhizosphere, they are by nature more similar to fertilising products than to most categories of plant protection products. They act in addition to fertilisers, with the aim of optimising the efficiency of those fertilisers and reducing the nutrient application rates. Such products should therefore be eligible for CE marking under this Regulation and excluded from the scope of Regulation (EC) No 1107/2009".

These two regulations attempt to classify the substances and products applicable to crops into two large groups: Those that are plant protectors (phyto-sanitary) (Regulation \#1) and those that can be used as fertilizers (Regulation \#2). As we have seen in the previous section, melatonin is classified as a health hazard substance (code H-361) for its reproductive toxicity in ECHA, so its possible authorization as an active substance by regulation EC 1907/2006 of Registration, Evaluation, Authorisation and Restriction of Chemicals (REACH) could be difficult.

Although Regulation \#1 on plant protection products extends the concept of an active substance, since it includes microorganisms and preparations (art. 1 point 2): This Regulation shall apply to substances, including micro-organisms having general or specific action against harmful organisms or on plants, parts of plants or plant products, referred to as 'active substances', some interesting restrictions appeared in:

- Art. 23b: "Basic substances shall be approved in accordance with paragraphs 2 to 6. ( . . ) For the purpose of paragraphs 2 to 6 , a basic substance is an active substance which (...), (b) does not have an inherent capacity to cause endocrine disrupting, neurotoxic or immunotoxic effects";

- Annex II, Impact on Human Health, 3.6.5: “An active substance, safener or synergist shall only be approved if, on the basis of the assessment of community or internationally agreed test guidelines or other available data and information, including a review of the scientific literature, reviewed by the Authority, it is not considered to have endocrine disrupting properties that may cause adverse effect in humans, unless the exposure of humans to that active substance, safener or synergist in a plant protection product, under realistic proposed conditions of use, is negligible, ... " and in;

- Annex II. Ecotoxicology, 3.8.2. An active substance, safener or synergist shall only be approved if, on the basis of the assessment of community or internationally agreed test guidelines, it is not considered to have endocrine disrupting properties that may cause adverse effects on non-target organisms unless the exposure of non-target organisms to that active substance in a plant protection product under realistic proposed conditions of use is negligible.

Thus, taking into account all this legal information, and ruling out the possibility of using melatonin as an active substance (pure chemical substance) for agronomic application, the possibility of using plant, bacterial, algae, or fungi extracts rich in melatonin would remain. Thus, a good plan 
might be to use plant (or other) extracts rich in melatonin as a fertilizer, in the category of biostimulants. A biostimulant could also be defined as a formulated product of biological origin that improves plant productivity as a consequence of the emergent properties of its constituents. Thus, biostimulants could be defined by their demonstrated mode of action and origin, or solely by their demonstrated beneficial impact on plant productivity. The challenges in developing a definition are also complicated by the multi-component and largely undefined composition of many biostimulant products and the possibility that the activity of a biostimulant may not be explained by the presence of any individual constituent, but is a result of the interaction of many constituents in the product. Indeed, most biostimulants in use today are complex mixtures of chemicals derived from a biological process or the extraction of biological materials [236].

According Regulation \#2 (EU 2019/1009) on fertilizing products, in Annex I, Product Function Categories (PFCs) of EU fertilizing products, in Category 6, two types of plant biostimulant can be developed: Microbial plant biostimulants (subtype A) and non-microbial plant biostimulants (subtype B). In Annex II, it says: "An EU fertilizing product shall consist solely of component materials complying with the requirements for one or more of the CMCs listed in this Annex", where the different component materials categories $(\mathrm{CMC})$ were defined. Of interest are the following:

- CMC2: Plants, plant parts or plant extracts is described as: “An EU fertilizing product may contain plants, plant parts or plant extracts having undergone no other processing than cutting, grinding, milling, sieving, sifting, centrifugation, pressing, drying, frost treatment, freeze-drying or extraction with water or supercritical $\mathrm{CO}_{2}$ extraction. For the purpose of this point, plants include mushrooms and algae and exclude blue-green algae (cyanobacteria)."

- CMC6: Food industry by-products, point (e): "Plants, plant parts or plant extracts having undergone only heat treatment or heat treatment in addition to processing methods referred to in CMC 2"

- CMC7: Micro-organisms. "An EU fertilising product belonging to PFC 6A may contain micro-organisms, including dead or empty-cell micro-organisms and non-harmful residual elements of the media on which they were produced".

The strategies to obtain melatonin-rich extracts may involve microorganisms (PFC6A) or plants (PFC 6B). At present, there seem to be no data on the production of melatonin by bacteria or fungal cultures. The objective to obtain melatonin-rich plants (CMC2) is ambitious since phytomelatonin levels in plants are usually very low, and less than $5-10$ ng per gram of plant. An exhaustive classification of many plants according to their phytomelatonin content can be consulted $[37,237,238]$. Generally, medicinal plants have high phytomelatonin content, but this tends to vary widely due to the varied origin of plants, technical conditions of growth, variety, post-harvest treatment, etc. Several strategies can be followed: (i) Selecting plant species with high levels of phytomelatonin which can be extracted and concentrated, and (ii) inducing the biosynthesis of phytomelatonin in in vitro cultured pre-selected plant tissues. A discussion on this aspect can be consulted [239]. Our group is developing a formulation where only aromatic/medicinal plants are used to obtain a botanical mixture rich in phytomelatonin through the application of a simple process. A rigorous plant selection protocol and careful management will ensure high phytomelatonin content in the plant extracts generated. The formulation and its protocol are being patented before being made available to interested companies for commercial exploitation. We are currently characterizing it and conducting the appropriate studies and bioassays in plants to confirm its beneficial biological activity related with its high phytomelatonin content.

Figure 2 shows, according to the legislation analyzed, the pros and cons of melatonin (as a chemical substance) and phytomelatonin-rich extracts and its possible regularization as a plant protector or fertilizer (biostimulant). 


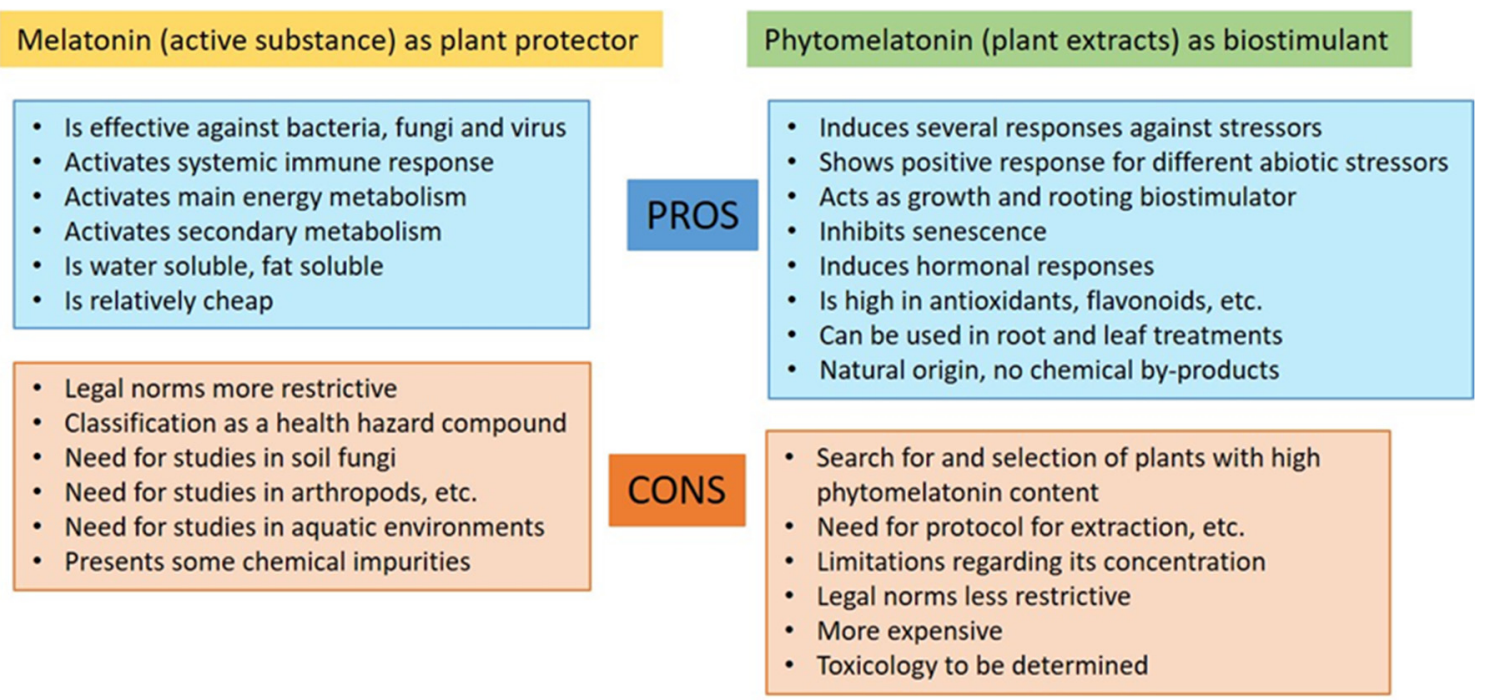

Figure 2. Pros and cons of the possible use of chemical melatonin and rich-phytomelatonin extracts according to EC legislation.

\section{Future Prospects}

Numerous studies with melatonin have resulted in a set of data that indicate the excellent beneficial effects that this compound has on plants, especially in stress situations. It should not be forgotten that melatonin is a natural compound, endogenous to plants and other organisms including humans. It is this last aspect that makes it more interesting and also more delicate or sensitive, when using it as a plant protective agent or as a biostimulator. However, demonstrating through trials that its use is possible in crops and does not entail risks to human and wildlife health will be the only way forward in this field. The alternative of using phytomelatonin-rich extracts seems more interesting, but also more laborious. The search and selection of plants with high endogenous levels of phytomelatonin is a first requirement for subsequent extraction and preparation. The analysis and study of its potential as a protector against plant stress will throw light on the true effect on crops. However, although many aspects of the mechanism of action of phytomelatonin are already known, there are other relevant aspects to study as: (i) The optimal mode of application, time and rate; (ii) the phenological state; (iii) the effect on rhizosphere; (iv) the persistence in soil or in foliar applications; (v) the synergic or antagonic effects with other plant treatments (pesticides, fertilizers, etc.), among others. Obviously, companies in the phytochemical sector (manufacturers) will need to start field studies and deal with possible legal regularization.

\section{Abbreviations}

$\begin{array}{ll}\text { ABA } & \text { abscisic acid } \\ \text { AGR } & \text { absolute growth rate } \\ \text { ASA } & \text { ascorbic acid } \\ \text { CGR } & \text { crop growth rate } \\ \text { Chls } & \text { chlorophylls } \\ \text { CMC } & \text { component materials categories of fertilizers } \\ \text { EC } & \text { European Community } \\ \text { ECHA } & \text { European Chemical Agency } \\ \text { EU } & \text { European Union } \\ \text { GA } 4 & \text { gibberellin-4 } \\ \text { GABA } & \gamma \text {-aminobutyric acid }\end{array}$




$\begin{array}{ll}\text { GSH } & \text { glutathione } \\ \text { JA } & \text { jasmonic acid } \\ \text { LAI } & \text { leaf area index } \\ \text { MDA } & \text { malondialdehyde } \\ \text { MAPKK } & \text { mitogen-activated protein kinase cascade } \\ \text { NAR } & \text { net assimilation rate } \\ \text { OXI1 } & \text { oxidative signal-inducible1 kinases } \\ \text { PFC } & \text { product function categories of fertilizers } \\ \text { ROS } & \text { reactive oxygen species } \\ \text { RWC } & \text { relative water content } \\ \text { SA } & \text { salicylic acid } \\ \text { SAR } & \text { systemic acquired resistance } \\ \text { TA } & \text { total valuable acidity } \\ \text { TCA } & \text { Krebs cycle } \\ \text { TSS } & \text { total solid soluble }\end{array}$

Author Contributions: The manuscript was conceived by M.B.A. and written and revised by M.B.A. and J.H.-R.

Funding: Not financial support available for this review.

Conflicts of Interest: The authors declare no conflicts of interest.

\section{References}

1. Lerner, A.B.; Case, J.D.; Takahashi, Y.; Lee, T.H.; Mori, W. Isolation of melatonin, a pineal factor that lightens melanocytes. J. Am. Chem. Soc. 1958, 80, 2587. [CrossRef]

2. Lerner, A.; Case, J.; Mori, W.; Wright, M. Melatonin in peripheral nerve. Nature 1959, 183, 1821. [CrossRef] [PubMed]

3. Lerner, A.; Case, J.; Heinzelmann, R. Structure of melatonin. J. Am. Chem. Soc. 1959, 81, 6084-6085. [CrossRef]

4. Xie, Z.; Chen, F.; Li, W.A.; Geng, X.; Li, C.; Meng, X.; Feng, Y.; Liu, W.; Yu, F. A review of sleep disorders and melatonin. Neurol. Res. 2017, 39, 559-565. [CrossRef] [PubMed]

5. Vadnie, C.A.; McClung, C.A. Circadian rhythm disturbances in mood disorders: Insights into the role of the suprachiasmatic nucleus. Neural Plast. 2017, 2017, 1504507. [CrossRef]

6. Carpentieri, A.R.; Oliva, C.; Díez-Noguera, A.; Cambras, T. Melatonin administration modifies circadian motor activity under constant light depending on the lighting conditions during suckling. Chronobiol. Int. 2015, 32, 994-1004. [PubMed]

7. Blume, C.; Angerer, M.; Raml, M.; del Giudice, R.; Santhi, N.; Pichler, G.; Kunz, A.B.; Scarpatetti, M.; Trinka, E.; Schabus, M. Healthier rhythm, healthier brain? Integrity of circadian melatonin and temperature rhythms relates to the clinical state of brain-injured patients. Eur. J. Neurol. 2019, 26, 1051-1059. [CrossRef]

8. Marková, M.; Adámeková, E.; Kubatka, P.; Bojková, B.; Ahlersová, E.; Ahlers, I. Effect of prolonged melatonin administration on metabolic parameters and organ weights in young male and female Sprague-Dawley rats. Acta Vet. Brno 2003, 72, 163-173. [CrossRef]

9. Bojková, B.; Marková, M.; Ahlersová, E.; Ahlers, I.; Adámeková, E.; Kubatka, P.; Kassayová, M. Metabolic effects of prolonged melatonin administration and short-term fasting in laboratory rats. Acta Vet. Brno 2006, 75, 21-32. [CrossRef]

10. Cardinali, D.P.; Hardeland, R. Inflammaging, metabolic syndrome and melatonin: A call for treatment studies. Neuroendocrinology 2017, 104, 382-397. [CrossRef]

11. Kubatka, P.; Bojková, B.; Mociková, K.; Mníchová, M.; Adámeková, E.; Ahlers, I.; Ahlersová, E.; Cermáková, M. Effects of tamoxifen and melatonin on mammary gland cancer induced by N-methyl-N-nitrosourea and by 7,12-dimethylbenz(a)anthracene, respectively, in female Sprague-Dawley rats. Folia Biologica (Praha) 2001, 47, 5-10.

12. Di Bella, G.; Mascia, F.; Gualano, L.; Di Bella, L. Melatonin anticancer effects: Review. Int. J. Mol. Sci. 2013, 14, 2410-2430. [CrossRef]

13. Bojková, B.; Kubatka, P.; Qaradakhi, T.; Zulli, A.; Kajo, K. Melatonin may increase anticancer potential of pleiotropic drugs. Molecules 2018, 19, 3910. [CrossRef] 
14. Nabavi, S.M.; Nabavi, S.F.; Sureda, A.; Xiao, J.; Dehpour, A.R.; Shirooie, S.; Silva, A.S.; Baldi, A.; Khan, H.; Daglia, M. Anti-inflammatory effects of melatonin: A mechanistic review. Crit. Rev. Food Sci. Nutr. 2019, 59, S4-S16. [CrossRef]

15. Carrascal, L.; Nuñez-Abades, P.; Ayala, A.; Cano, M. Role of melatonin in the inflammatory process and its therapeutic potential. Curr. Pharm. Des. 2018, 24, 1563-1588. [CrossRef]

16. Carrillo-Vico, A.; Guerrero, J.M.; Lardone, P.J.; Reiter, R.J. A review of the multiple actions of melatonin on the immune system. Endocrine 2012, 27, 189-200. [CrossRef]

17. Reiter, J.R.; Rosales-Corral, A.S.; Tan, D.X.; cuna-Castroviejo, D.; Qin, L.; Yang, S.F.; Xu, K. Melatonin, a full service anti-cancer agent: Inhibition of initiation, progression and metastasis. Int. J. Mol. Sci. 2017, 18, 843. [CrossRef]

18. Majidinia, M.; Reiter, R.J.; Shakouri, S.K.; Yousefi, B. The role of melatonin, a multitasking molecule, in retarding the processes of ageing. Ageing Res. Rev. 2018, 47, 198-213. [CrossRef]

19. Boga, J.A.; Caballero, B.; Potes, Y.; Perez-Martinez, Z.; Reiter, R.J.; Vega-Naredo, I.; Coto-Montes, A. Therapeutic potential of melatonin related to its role as an autophagy regulator: A review. J. Pineal Res. 2019, 66, e12534. [CrossRef]

20. Luo, C.; Yang, Q.; Liu, Y.; Zhou, S.; Jiang, J.; Reiter, R.J.; Bhattacharya, P.; Cui, Y.; Yang, H.; Ma, H.; et al. The multiple protective roles and molecular mechanisms of melatonin and its precursor $\mathrm{N}$-acetylserotonin in targeting brain injury and liver damage and in maintaining bone health. Free Radic. Biol. Med. 2019, 130, 215-233. [CrossRef]

21. Arnao, M.B.; Hernández-Ruiz, J. Melatonin: Synthesis from tryptophan and its role in higher plants. In Amino Acids in Higher Plants; D' Mello, J.P.F., Ed.; CAB Intern.: Boston, MA, USA, 2015; pp. 390-435.

22. Jan, J.E.; Reiter, R.J.; Wasdell, M.B.; Bax, M. The role of the thalamus in sleep, pineal melatonin production, and circadian rhythm sleep disorders. J. Pineal Res. 2009, 46, 1-7. [CrossRef]

23. McHill, A.W.; Phillips, A.J.; Czeisler, C.A.; Keating, L.; Yee, K.; Barger, L.K.; Garaulet, M.; Scheer, F.A.; Klerman, E.B. Later circadian timing of food intake is associated with increased body fat. Am. J. Clin. Nutr. 2017, 106, 1213-1219. [CrossRef]

24. Dubbels, R.; Reiter, R.J.; Klenke, E.; Goebel, A.; Schnakenberg, E.; Ehlers, C.; Schiwara, H.W.; Schloot, W. Melatonin in edible plants identified by radioimmunoassay and by HPLC-MS. J. Pineal Res. 1995, 18, $28-31$. [CrossRef]

25. Hattori, A.; Migitaka, H.; Iigo, M.; Yamamoto, K.; Ohtani-Kaneko, R.; Hara, M.; Suzuki, T.; Reiter, R.J. Identification of melatonin in plants and its effects on plasma melatonin levels and binding to melatonin receptors in vertebrates. Biochem. Mol. Biol. Int. 1995, 35, 627-634.

26. Kolar, J.; Machackova, I.; Illnerova, H.; Prinsen, E.; van Dongen, W.; van Onckelen, H. Melatonin in higher plant determined by radioimmunoassay and liquid chromatography-mass spectrometry. Biol. Rhythm Res. 1995, 26, 406-409.

27. van Tassel, D.L.; Roberts, N.; O'Neill, S.D. Melatonin from higher plants: Isolation and identification of N-acetyl-5-methoxytryptamine. Plant Physiol. 1995, 108, 101.

28. Back, K.; Tan, D.X.; Reiter, R.J. Melatonin biosynthesis in plants: Multiple pathways catalyze tryptophan to melatonin in the cytoplasm or chloroplasts. J. Pineal Res. 2016, 61, 426-437. [CrossRef]

29. Zheng, X.; Tan, D.X.; Allan, A.C.; Zuo, B.; Zhao, Y.; Reiter, R.J.; Wang, L.; Wang, Z.; Guo, Y.; Zhou, J.; et al. Chloroplastic biosynthesis of melatonin and its involvement in protection of plants from salt stress. Sci. Rep. 2017, 7, 41236. [CrossRef]

30. Wang, L.; Feng, C.; Zheng, X.; Guo, Y.; Zhou, F.; Shan, D.; Liu, X.; Kong, J. Plant mitochondria synthesize melatonin and enhance the tolerance of plants to drought stress. J. Pineal Res. 2017, 63, e12429. [CrossRef]

31. Arnao, M.B.; Hernández-Ruiz, J. Melatonin: A new plant hormone and/or a plant master regulator? Trends Plant Sci. 2019, 24, 38-48. [CrossRef]

32. Arnao, M.B.; Hernández-Ruiz, J. Melatonin in its relationship to plant hormones. Ann. Bot. 2018, 121, 195-207. [CrossRef]

33. Arnao, M.B.; Hernández-Ruiz, J. The multi-regulatory properties of melatonin in plants. In Neurotransmitters in Plants; Roshchina, V.V., Ramakrishna, A., Eds.; Taylor \& Francis-CRC: New York, NY, USA, 2018; pp. 71-101.

34. Sharif, R.; Xie, C.; Zhang, H.; Arnao, M.; Ali, M.; Ali, Q.; Muhammad, I.; Shalmani, A.; Nawaz, M.; Chen, P.; et al. Melatonin and its effects on plant systems. Molecules 2018, 23, 2352. [CrossRef] 
35. Arnao, M.B.; Hernández-Ruiz, J. Growth activity, rooting capacity, and tropism: Three auxinic precepts fulfilled by melatonin. Acta Physiol. Plant 2017, 39, 127. [CrossRef]

36. Arnao, M.B.; Hernández-Ruiz, J. Functions of melatonin in plants: A review. J. Pineal Res. 2015, 59, $133-150$. [CrossRef]

37. Arnao, M.B. Phytomelatonin: Discovery, content, and role in plants. Adv. Bot. 2014, 2014, e815769. [CrossRef]

38. Wang, Y.; Reiter, R.J.; Chan, Z. Phytomelatonin: A universal abiotic stress regulator. J. Exp. Bot. 2018, 69, 963-974. [CrossRef]

39. Reiter, R.J.; Rosales-Corral, S.; Tan, D.X.; Jou, M.J.; Galano, A.; Xu, B. Melatonin as a mitochondria-targeted antioxidant: One of evolution's best ideas. Cell Mol. Life Sci. 2017, 74, 3863-3881. [CrossRef]

40. Debnath, B.; Islam, W.; Li, M.; Sun, Y.; Lu, X.; Mitra, S.; Hussain, M.; Liu, S.; Qiu, D. Melatonin mediates enhancement of stress tolerance in plants. Int. J. Mol. Sci. 2019, 20, 1040. [CrossRef]

41. Yu, Y.; Lv, Y.; Shi, Y.; Li, T.; Chen, Y.; Zhao, D.; Zhao, Z. The role of phyto-melatonin and related metabolites in response to stress. Molecules 2018, 23, 1887. [CrossRef]

42. Shibaeva, T.G.; Markovskaya, E.F.; Mamaev, A.V. Phytomelatonin: A review. Biol. Bull. Rev. 2018, 8, 375-388. [CrossRef]

43. Arnao, M.B.; Hernández-Ruiz, J. Melatonin and reactive oxygen and nitrogen species: A model for the plant redox network. Melatonin Res. 2019, 2, 152-168. [CrossRef]

44. Zhang, X.; Schmidt, R. The impact of growth regulators on a-tocopherol status of water-stressed Poa pratensis L. Int. Turfgrass Soc. Res. J. 1997, 8, 1364-1373.

45. Kauffman, G.L.; Kneivel, D.P.; Watschke, T.L. Effects of a biostimulant on the heat tolerance associated with photosynthetic capacity, membrane thermostability, and polyphenol production of perennial ryegrass. Crop Sci. 2007, 47, 261-267. [CrossRef]

46. du Jardin, P. Plant biostimulants: Definition, concept, main categories and regulation. Sci. Hort. 2015, 196, 3-14. [CrossRef]

47. Rouphael, Y.; Colla, G. Synergistic Biostimulatory Action: Designing the Next Generation of Plant Biostimulants for Sustainable Agriculture. Front. Plant Sci. 2018, 9, 1655. [CrossRef]

48. Rouphael, Y.; SpÍchal, L.; Panzarová, K.; Casa, R.; Colla, G. High-Throughput plant phenotyping for developing novel biostimulants: From lab to field or from field to lab? Front. Plant Sci. 2018, 9, 1197. [CrossRef]

49. Afreen, F.; Zobayed, S.M.A.; Kozai, T. Melatonin in Glycyrrhiza uralensis: Response of plant roots to spectral quality of light and UV-B radiation. J. Pineal Res. 2006, 41, 108-115. [CrossRef]

50. Lei, X.Y.; Zhu, R.Y.; Zhang, G.Y.; Dai, Y.R. Attenuation of cold-induced apoptosis by exogenous melatonin in carrot suspension cells: The possible involvement of polyamines. J. Pineal Res. 2004, 36, 126-131. [CrossRef]

51. Arnao, M.B.; Hernández-Ruiz, J. The physiological function of melatonin in plants. Plant Sign. Behav. 2006, 1, 89-95. [CrossRef]

52. Fletcher, R.; Sopher, C. Retardation of leaf senescence by melatonin indicates that it acts as an antioxidant in plants. In Proceedings of the 5th Canadian Pineal and Melatonin Symposium, Guelph, ON, Canada, 13-15 July 1997.

53. Hardeland, R.; Pandi-Perumal, S.; Poeggeler, B. Melatonin in plants: Focus on a vertebrate night hormone with cytoprotective properties. Funct. Plant Sci. Biotechnol. 2007, 1, 32-45.

54. Reiter, R.J.; Korkmaz, A.; Paredes, S.D.; Manchester, L.C.; Tan, D.X. Melatonin reduces oxidative/nitrosative stress due to drugs, toxins, metals, and herbicides. Neuro Endocrinol. Lett. 2008, 29, 609-613.

55. Paredes, S.D.; Korkmaz, A.; Manchester, L.C.; Tan, D.X.; Reiter, R.J. Phytomelatonin: A review. J. Exp. Bot. 2009, 60, 57-69. [CrossRef]

56. Posmyk, M.; Janas, K. Melatonin in plants. Acta Physiol. Plant 2009, 31, 1-11. [CrossRef]

57. Reiter, R.J.; Paredes, S.D.; Manchester, L.C.; Tan, D.X. Reducing oxidative/nitrosative stress: A newly-discovered genre for melatonin. Crit. Rev. Biochem. Mol. Biol. 2009, 44, 175-200. [CrossRef]

58. Hernández-Ruiz, J.; Cano, A.; Arnao, M.B. Melatonin: Growth-stimulating compound present in lupin tissues. Planta 2004, 220, 140-144. [CrossRef]

59. Hernández-Ruiz, J.; Cano, A.; Arnao, M.B. Melatonin acts as a growth-stimulating compound in some monocot species. J. Pineal Res. 2005, 39, 137-142. [CrossRef]

60. Arnao, M.B.; Hernández-Ruiz, J. Melatonin promotes adventitious and lateral root regeneration in etiolated hypocotyls of Lupinus albus L. J. Pineal Res. 2007, 42, 147-152. [CrossRef] 
61. Arnao, M.B.; Hernández-Ruiz, J. Melatonin in plants. More studies are necessary. Plant Sign. Behav. 2007, 2, 381-382. [CrossRef]

62. Hernández-Ruiz, J.; Arnao, M.B. Melatonin stimulates the expansion of etiolated lupin cotyledons. Plant Growth Regul. 2008, 55, 29-34. [CrossRef]

63. Park, W.J. Melatonin as an endogenous plant regulatory signal: Debates and perspectives. J. Plant Biol. 2011, 54, 143-149. [CrossRef]

64. Tan, D.X.; Hardeland, R.; Manchester, L.C.; Korkmaz, A.; Ma, S.; Rosales-Corral, S.; Reiter, R.J. Functional roles of melatonin in plants, and perspectives in nutritional and agricultural science. J. Exp. Bot. 2012, 63, 577-597. [CrossRef]

65. Byeon, Y.; Park, S.; Kim, Y.S.; Back, K. Microarray analysis of genes differentially expressed in melatonin-rich transgenic rice expressing a sheep serotonin N-acetyltransferase. J. Pineal Res. 2013, 55, 357-363.

66. Arnao, M.B.; Hernández-Ruiz, J. Melatonin: Plant growth regulator and/or biostimulator during stress? Trends Plant Sci. 2014, 19, 789-797. [CrossRef]

67. Wang, P.; Sun, X.; Xie, Y.; Li, M.; Chen, W.; Zhang, S.; Liang, D.; Ma, F. Melatonin regulates proteomic changes during leaf senescence in Malus Hupehensis. J. Pineal Res. 2014, 57, 291-307. [CrossRef]

68. Weeda, S.; Zhang, N.; Zhao, X.; Ndip, G.; Guo, Y.D.; Buck, G.; Fu, C.; Ren, S. Arabidopsis transcriptome analysis reveals key roles of melatonin in plant defense systems. PLoS ONE 2014, 9, e93462. [CrossRef]

69. Zhang, H.J.; Zhang, N.; Yang, R.C.; Wang, L.; Sun, Q.Q.; Li, D.B.; Cao, Y.Y.; Weeda, S.; Zhao, B.; Ren, S.; et al. Melatonin promotes seed germination under high salinity by regulating antioxidant systems, ABA and $\mathrm{GA}_{4}$ interaction in cucumber (Cucumis sativus L.). J. Pineal Res. 2014, 57, 269-279. [CrossRef]

70. Zhang, N.; Zhang, H.J.; Zhao, B.; Sun, Q.Q.; Cao, Y.Y.; Li, R.; Wu, X.X.; Weeda, S.; Li, L.; Ren, S.; et al. The RNA-seq approach to discriminate gene expression profiles in response to melatonin on cucumber lateral root formation. J. Pineal Res. 2014, 56, 39-50. [CrossRef]

71. Li, C.; Liang, D.; Chang, C.; Jia, D.; Ma, F. Melatonin mediates the regulation of ABA metabolism, free-radical scavenging, and stomatal behavior in two Malus species under drought stress. J. Exp. Bot. 2015, 66, 669-680. [CrossRef]

72. Li, X.; Tan, D.X.; Jiang, D.; Liu, F. Melatonin enhances cold tolerance in drought-primed wild-type and abscisic acid-deficient mutant barley. J. Pineal Res. 2016, 61, 328-339. [CrossRef]

73. Liu, J.; Zhai, R.; Liu, F.; Zhao, Y.; Wang, H.; Liu, L.; Yang, C.; Wang, Z.; Ma, F.; Xu, L. Melatonin induces parthenocarpy by regulating genes in gibberellin pathways in 'Starkrimson' pear (Pyrus communis L.). Front. Plant Sci. 2018, 9, 946. [CrossRef]

74. Sun, Q.Q.; Zhang, N.; Wang, J.; Zhang, H.J.; Li, D.B.; Shi, J.; Li, R.; Weeda, S.; Zhao, B.; Ren, S.; et al. Melatonin promotes ripening and improves quality of tomato fruit during postharvest life. J. Exp. Bot. 2015, 66, 657-668. [CrossRef]

75. Hernández-Ruiz, J.; Arnao, B.M. Relationship of melatonin and salicylic acid in biotic/abiotic plant stress responses. Agronomy 2018, 8, 33. [CrossRef]

76. Erland, L.A.E.; Murch, S.J.; Reiter, R.J.; Saxena, P.K. A new balancing act: The many roles of melatonin and serotonin in plant growth and development. Plant Sign. Behav. 2015, 10, e1096469. [CrossRef]

77. Reiter, R.J.; Tan, D.X.; Zhou, Z.; Coelho-Cruz, M.H.; Fuentes-Broto, L.; Galano, A. Phytomelatonin: Assisting plants to survive and thrive. Molecules 2015, 20, 7396-7437. [CrossRef]

78. Tan, D.X. Melatonin and plants. J. Exp. Bot. 2015, 66, 1-2. [CrossRef]

79. Tan, D.X.; Manchester, C.L.; Esteban-Zubero, E.; Zhou, Z.; Reiter, J.R. Melatonin as a potent and inducible endogenous antioxidant: Synthesis and metabolism. Molecules 2015, 20, 18886-18906. [CrossRef]

80. Zhang, N.; Sun, Q.; Zhang, H.; Cao, Y.; Weeda, S.; Ren, S.; Guo, Y.D. Roles of melatonin in abiotic stress resistance in plants. J. Exp. Bot. 2015, 66, 647-656. [CrossRef]

81. Hardeland, R. Melatonin in plants. Diversity of levels and multiplicity of functions. Front. Plant Sci. 2016, 7, 198. [CrossRef]

82. Nawaz, M.A.; Huang, Y.; Bie, Z.; Ahmad, W.; Reiter, R.J.; Niu, M.; Hameed, S. Melatonin: Current status and future perspectives in plant science. Front. Plant Sci. 2016, 6, 1230. [CrossRef]

83. Erland, L.A.E.; Saxena, P.K. Melatonin in plant morphogenesis. In Vitro Cell. Dev. Biol. Plant 2018, 54, 3-24. [CrossRef] 
84. Fazal, H.; Abbasi, B.H.; Ahmad, N.; Ali, M. Exogenous melatonin trigger biomass accumulation and production of stress enzymes during callogenesis in medicinally important Prunella vulgaris L. (Selfheal). Physiol. Mol. Biol. Plants 2018, 24, 1307-1315. [CrossRef]

85. Kanwar, M.K.; Yu, J.; Zhou, J. Phytomelatonin: Recent advances and future prospects. J. Pineal Res. 2018, 65, e12526. [CrossRef]

86. Wei, J.; Li, D.; Zhang, J.; Shan, C.; Rengel, Z.; Song, Z.; Chen, Q. Phytomelatonin receptor PMTR1-mediated signaling regulates stomatal closure in Arabidopsis thaliana. J. Pineal Res. 2018, 65, e12500. [CrossRef]

87. Yoon, H.Y.; Kim, M.; Park, J.W. Foliar accumulation of melatonin applied to the roots of maize (Zea mays) seedlings. Biomolecules 2019, 9, 26. [CrossRef]

88. Li, H.; Chang, J.; Zheng, J.; Dong, Y.; Liu, Q.; Yang, X.; Wei, C.; Zhang, Y.; Ma, J.; Zhang, X. Local melatonin application induces cold tolerance in distant organs of Citrullus lanatus L. via long distance transport. Sci. Rep. 2017, 7, 40858. [CrossRef]

89. Zhang, Q.; Liu, X.; Zhang, Z.; Liu, N.; Li, D.; Hu, L. Melatonin improved waterlogging tolerance in alfalfa (Medicago sativa) by reprogramming polyamine and ethylene metabolism. Front. Plant Sci. 2019, 10, 44. [CrossRef]

90. Gu, Q.; Chen, Z.; Yu, X.; Cui, W.; Pan, J.; Zhao, G.; Xu, S.; Wang, R.; Shen, W. Melatonin confers plant tolerance against cadmium stress via the decrease of cadmium accumulation and reestablishment of microRNA-mediated redox homeostasis. Plant Sci. 2017, 261, 28-37. [CrossRef]

91. Chen, Z.; Gu, Q.; Yu, X.; Huang, L.; Xu, S.; Wang, R.; Shen, W.; Shen, W. Hydrogen peroxide acts downstream of melatonin to induce lateral root formation. Ann. Bot. 2018, 121, 1127-1136. [CrossRef]

92. Li, C.; Wang, P.; Wei, Z.; Liang, D.; Jia, D.; Fu, M.; Ma, F. The mitigation effects of exogenous melatonin on salinity-induced stress in Malus hupehensis. J. Pineal Res. 2012, 53, 298-306. [CrossRef]

93. Li, C.; Liang, B.; Chang, C.; Wei, Z.; Zhou, S.; Ma, F. Exogenous melatonin improved potassium content in Malus under different stress conditions. J. Pineal Res. 2016, 61, 218-229. [CrossRef]

94. Wang, P.; Sun, X.; Li, C.; Wei, Z.; Liang, D.; Ma, F. Long-term exogenous application of melatonin delays drought-induced leaf senescence in apple. J. Pineal Res. 2013, 54, 292-302. [CrossRef]

95. Zuo, B.; Zheng, X.; He, P.; Wang, L.; Lei, Q.; Feng, C.; Zhou, J.; Li, Q.; Han, Z.; Kong, J. Overexpression of MzASMT improves melatonin production and enhances drought tolerance in transgenic Arabidopsis thaliana plants. J. Pineal Res. 2014, 57, 408-417. [CrossRef]

96. Liang, B.; Ma, C.; Zhang, Z.; Wei, Z.; Gao, T.; Zhao, Q.; Ma, F.; Li, C. Long-term exogenous application of melatonin improves nutrient uptake fluxes in apple plants under moderate drought stress. Environ. Exp. Bot. 2018, 155, 650-661. [CrossRef]

97. Zheng, X.; Zhou, J.; Tan, D.X.; Wang, N.; Wang, L.; Shan, D.; Kong, J. Melatonin improves waterlogging tolerance of Malus baccata (Linn.) Borkh. seedlings by maintaining aerobic respiration, photosynthesis and ROS migration. Front. Plant Sci. 2017, 8, 483. [CrossRef]

98. Gong, X.; Shi, S.; Dou, F.; Song, Y.; Ma, F. Exogenous melatonin alleviates alkaline stress in Malus hupehensis Rehd. by regulating the biosynthesis of polyamines. Molecules 2017, 22, 1542. [CrossRef]

99. Wang, P.; Yin, L.; Liang, D.; Li, C.; Ma, F.; Yue, Z. Delayed senescence of apple leaves by exogenous melatonin treatment: Toward regulating the ascorbate-glutathione cycle. J. Pineal Res. 2012, 53, 11-20. [CrossRef]

100. Wang, P.; Sun, X.; Chang, C.; Feng, F.; Liang, D.; Cheng, L.; Ma, F. Delay in leaf senescence of Malus hupehensis by long-term melatonin application is associated with its regulation of metabolic status and protein degradation. J. Pineal Res. 2013, 55, 424-434.

101. Yin, L.; Wang, P.; Li, M.; Ke, X.; Li, C.; Liang, D.; Wu, S.; Ma, X.; Li, C.; Zou, Y.; et al. Exogenous melatonin improves Malus resistance to Marssonina apple blotch. J. Pineal Res. 2013, 54, 426-434. [CrossRef]

102. Li, C.; Zhao, Q.; Gao, T.; Wang, H.; Zhang, Z.; Liang, B.; Wei, Z.; Liu, C.; Ma, F. The mitigation effects of exogenous melatonin on replant disease in apple. J. Pineal Res. 2018, 65, e12523. [CrossRef]

103. Chen, L.; Wang, M.R.; Li, J.W.; Feng, C.H.; Cui, Z.H.; Zhao, L.; Wang, Q.C. Exogenous application of melatonin improves eradication of apple stem grooving virus from the infected in-vitro shoots by shoot tip culture. Plant Pathol. 2019, 68, 997-1006. [CrossRef]

104. Mohamed Abd El-Naby, S.; Ahmed Mohamed, A.; Mohamed El-Naggar, Y. Effect of melatonin, GA 3 and NAA on vegetative growth, yield and quality of Canino apricot fruits. Acta Sci. Pol. Hortorum Cultus 2019, 18, 167-174. 
105. Hu, W.; Yang, H.; Tie, W.; Yan, Y.; Ding, Z.; Liu, Y.; Wu, C.; Wang, J.; Reiter, R.J.; Tan, D.X.; et al. Natural Variation in Banana Varieties Highlights the Role of Melatonin in Postharvest Ripening and Quality. J. Agric. Food Chem. 2017, 65, 9987-9994. [CrossRef]

106. Li, T.; Wu, Q.; Zhu, H.; Zhou, Y.; Jiang, Y.; Gao, H.; Yun, Z. Comparative transcriptomic and metabolic analysis reveals the effect of melatonin on delaying anthracnose incidence upon postharvest banana fruit peel. BMC Plant Biol. 2019, 19, 289. [CrossRef]

107. Arnao, M.B.; Hernández-Ruiz, J. Protective effect of melatonin against chlorophyll degradation during the senescence of barley leaves. J. Pineal Res. 2009, 46, 58-63. [CrossRef]

108. Shi, H.; Jiang, C.; Ye, T.; Tan, D.; Reiter, R.J.; Zhang, H.; Liu, R.; Chan, Z. Comparative physiological, metabolomic, and transcriptomic analyses reveal mechanisms of improved abiotic stress resistance in bermudagrass [Cynodon dactylon (L). Pers.] by exogenous melatonin. J. Exp. Bot. 2015, 66, 681-694. [CrossRef]

109. Fan, J.; Hu, Z.; Xie, Y.; Chan, Z.; Chen, K.; Amombo, E.; Chen, L.; Fu, J. Alleviation of cold damage to photosystem II and metabolisms by melatonin in Bermudagrass. Front. Plant Sci. 2015, 6, 925. [CrossRef]

110. Gul, M.; Khan, D.; Wani, A.; Bhat, S.; Mir, S.; Malik, A.; Kumar, A.; Narayan, S.; Stephen, K.; Lone, A. Foliar application of melatonin modulates the growth and photosynthetic pigments in broccoli cv. Palam Samridhi. SKUAST J. Res. 2018, 20, 193-198.

111. Posmyk, M.M.; Kuran, H.; Marciniak, K.; Janas, K.M. Presowing seed treatment with melatonin protects red cabbage seedlings against toxic copper ion concentrations. J. Pineal Res. 2008, 45, 24-31. [CrossRef]

112. Zhang, N.; Sun, Q.; Li, H.; Cao, Y.; Zhang, H.; Li, S.; Zhang, L.; Qi, Y.; Ren, S.; Zhao, B.; et al. Melatonin improved anthocyanin accumulation by regulating gene expressions and resulted in high reactive oxygen species scavenging capacity in cabbage. Front. Plant Sci. 2016, 7, 197. [CrossRef]

113. Tan, X.L.; Fan, Z.; Kuang, J.; Lu, W.; Reiter, R.J.; Lakshmanan, P.; Su, X.; Zhou, J.; Chen, J.; Shan, W. Melatonin delays leaf senescence of Chinese flowering cabbage by suppressing ABFs-mediated abscisic acid biosynthesis and chlorophyll degradation. J. Pineal Res. 2019, 67, e12570. [CrossRef]

114. Hu, W.; Kong, H.; Guo, Y.; Zhang, Y.; Ding, Z.; Tie, W.; Yan, Y.; Huang, Q.; Peng, M.; Shi, H.; et al. Comparative physiological and transcriptomic analyses reveal the actions of melatonin in the delay of postharvest physiological deterioration of cassava. Front. Plant Sci. 2016, 7, 736. [CrossRef]

115. Wei, Y.; Chang, Y.; Zeng, H.; Liu, G.; He, C.; Shi, H. RAV transcription factors are essential for disease resistance against cassava bacterial blight via activation of melatonin biosynthesis genes. J. Pineal Res. 2018, 64, e12454. [CrossRef]

116. Sarropoulou, V.N.; Therios, I.N.; Dimassi-Theriou, K.N. Melatonin promotes adventitious root regeneration in in vitro shoot tip explants of the commercial sweet cherry rootstocks CAB-6P (Prunus cerasus L.), Gisela 6 (P. cerasus $x$ P. canescens), and MxM 60 (P. avium $x$ P.mahaleb). J. Pineal Res. 2012, 52, 38-46. [CrossRef]

117. Sarropoulou, V.N.; Dimassi-Theriou, K.N.; Therios, I.N.; Koukourikou-Petridou, M. Melatonin enhances root regeneration, photosynthetic pigments, biomass, total carbohydrates and proline content in the cherry rootstock PHL-C (Prunus avium x Prunus cerasus). Plant Physiol. Biochem. 2012, 61, 162-168. [CrossRef]

118. Tijero, V.; Muñoz, P.; Munné-Bosch, S. Melatonin as an inhibitor of sweet cherries ripening in orchard trees. Plant Physiol. Biochem. 2019, 140, 88-95. [CrossRef]

119. Kostopoulou, Z.; Therios, I.; Roumeliotis, E.; Kanellis, A.K.; Molassiotis, A. Melatonin combined with ascorbic acid provides salt adaptation in Citrus aurantium L. seedlings. Plant Physiol. Biochem. 2015, 86, 155-165. [CrossRef]

120. Campos, C.N.; Avila, R.G.; de Souza, K.R.D.; Azevedo, L.M.; Alves, J.D. Melatonin reduces oxidative stress and promotes drought tolerance in young Coffea arabica L. plants. Agric. Water Manag. 2019, 211, 37-47. [CrossRef]

121. Xiao, S.; Liu, L.; Wang, H.; Li, D.; Bai, Z.; Zhang, Y.; Sun, H.; Zhang, K.; Li, C. Exogenous melatonin accelerates seed germination in cotton (Gossypium hirsutum L.). PLoS ONE 2019, 14, e0216575. [CrossRef]

122. Posmyk, M.M.; Balabusta, M.; Wieczorek, M.; Sliwinska, E.; Janas, K.M. Melatonin applied to cucumber (Cucumis sativus L.) seeds improves germination during chilling stress. J. Pineal Res. 2009, 46, 214-223. [CrossRef]

123. Balabusta, M.; Szafranska, K.; Posmyk, M.M. Exogenous melatonin improves antioxidant defense in cucumber seeds germinated under chilling stress. Front. Plant Sci. 2016, 7, 575. 
124. Zhao, H.; Zhang, K.; Zhou, X.; Xi, L.; Wang, Y.; Xu, H.; Pan, T.; Zou, Z. Melatonin alleviates chilling stress in cucumber seedlings by up-regulation of CsZat12 and modulation of polyamine and abscisic acid metabolism. Sci. Rep. 2017, 7, 4998. [CrossRef]

125. Zhao, H.; Ye, L.; Wang, Y.; Zhou, X.; Yang, J.; Wang, J.; Cao, K.; Zou, Z. Melatonin increases the chilling tolerance of chloroplast in cucumber seedlings by regulating photosynthetic electron flux and the ascorbate-glutathione cycle. Front. Plant Sci. 2016, 7, 1814. [CrossRef]

126. Zhao, N.; Sun, Y.; Wang, D.Y.; Zheng, J.X. Effects of exogenous melatonin on nitrogen metabolism in cucumber seedlings under high temperature stress. Zhiwu Shengli Xuebao/Plant Physiol. J. 2012, 48, 557-564.

127. Zhang, R.; Sun, Y.; Liu, Z.; Jin, W.; Sun, Y. Effects of melatonin on seedling growth, mineral nutrition, and nitrogen metabolism in cucumber under nitrate stress. J. Pineal Res. 2017, 62, e12403. [CrossRef]

128. Wang, L.Y.; Liu, J.L.; Wang, W.X.; Sun, Y. Exogenous melatonin improves growth and photosynthetic capacity of cucumbers under salinity-induced stress. Photosynthetica 2015, 54, 1-10. [CrossRef]

129. Zhang, N.; Zhang, H.J.; Sun, Q.Q.; Cao, Y.Y.; Li, X.; Zhao, B.; Wu, P.; Guo, Y.D. Proteomic analysis reveals a role of melatonin in promoting cucumber seed germination under high salinity by regulating energy production. Sci. Rep. 2017, 7, 503. [CrossRef]

130. Zhang, N.; Zhao, B.; Zhang, H.J.; Weeda, S.; Yang, C.; Yang, Z.C.; Ren, S.; Guo, Y.D. Melatonin promotes water-stress tolerance, lateral root formation, and seed germination in cucumber (Cucumis sativus L.). J. Pineal Res. 2013, 54, 15-23. [CrossRef]

131. Li, H.; He, J.; Yang, X.; Li, X.; Luo, D.; Wei, C.; Ma, J.; Zhang, Y.; Yang, J.; Zhang, X. Glutathione-dependent induction of local and systemic defense against oxidative stress by exogenous melatonin in cucumber (Cucumis sativus L.). J. Pineal Res. 2016, 60, 206-216. [CrossRef]

132. Cao, Y.Y.; Qi, C.D.; Li, S.; Wang, Z.; Wang, X.; Wang, J.; Ren, S.; Li, X.; Zhang, N.; Guo, Y.D. Melatonin alleviates copper toxicity via improving copper sequestration and ROS scavenging in Cucumber. Plant Cell Physiol. 2018, 60, 562-574. [CrossRef]

133. Li, J.; Li, Y.; Tian, Y.; Qu, M.; Zhang, W.; Gao, L. Melatonin has the potential to alleviate cinnamic acid stress in cucumber seedlings. Front. Plant Sci. 2017, 8, 1193. [CrossRef]

134. Dawood, M.G.; El-Awadi, M.E. Alleviation of salinity stress on Vicia faba L. plants via seed priming with melatonin. Acta Biol. Colomb. 2015, 20, 223-235. [CrossRef]

135. Meng, J.F.; Xu, T.F.; Wang, Z.Z.; Fang, Y.L.; Xi, Z.M.; Zhang, Z.W. The ameliorative effects of exogenous melatonin on grape cuttings under water-deficient stress: Antioxidant metabolites, leaf anatomy, and chloroplast morphology. J. Pineal Res. 2014, 57, 200-212. [CrossRef]

136. Ma, Y.; Jiao, J.; Fan, X.; Sun, H.; Zhang, Y.; Jiang, J.; Liu, C. Endophytic bacterium Pseudomonas fluorescens RG11 may transform tryptophan to melatonin and promote endogenous melatonin levels in the roots of four grape cultivars. Front. Plant Sci. 2017, 7, 2068. [CrossRef]

137. Xu, L.; Yue, Q.; Bian, F.E.; Sun, H.; Zhai, H.; Yao, Y. Melatonin enhances phenolics accumulation partially via ethylene signaling and resulted in high antioxidant capacity in grape berries. Front. Plant Sci. 2017, 8, 1426. [CrossRef]

138. Xu, L.; Yue, Q.; BIAN, F.; Zhai, H.; Yao, Y. Melatonin Treatment Enhances the Polyphenol Content and Antioxidant Capacity of Red Wine. Hortic. Plant J. 2018, 4, 144-150. [CrossRef]

139. Meng, J.F.; Xu, T.F.; Song, C.Z.; Yu, Y.; Hu, F.; Zhang, L.; Zhang, Z.W.; Xi, Z.M. Melatonin treatment of pre-veraison grape berries to increase size and synchronicity of berries and modify wine aroma components. Food Chem. 2015, 185, 127-134. [CrossRef]

140. Liang, D.; Ni, Z.; Xia, H.; Xie, Y.; Lv, X.; Wang, J.; Lin, L.; Deng, Q.; Luo, X. Exogenous melatonin promotes biomass accumulation and photosynthesis of kiwifruit seedlings under drought stress. Sci. Hort. 2019, 246, 34-43. [CrossRef]

141. Liang, D.; Shen, Y.; Ni, Z.; Wang, Q.; Lei, Z.; Xu, N.; Deng, Q.; Lin, L.; Wang, J.; Lv, X.; et al. Exogenous melatonin application delays senescence of kiwifruit leaves by regulating the antioxidant capacity and biosynthesis of flavonoids. Front. Plant Sci. 2018, 9, 426. [CrossRef]

142. Liang, D.; Gao, F.; Ni, Z.; Lin, L.; Deng, Q.; Tang, Y.; Wang, X.; Luo, X.; Xia, H. Melatonin improves heat tolerance in kiwifruit seedlings through promoting antioxidant enzymatic activity and glutathione S-transferase transcription. Molecules 2018, 23, 584. [CrossRef]

143. Hanci, F.; Çingi, M.; AKINCI, H. Influence of L-tryptophan and melatonin on germination of onion and leek seeds at different temperatures. Turk. J. Agric. Res. 2019, 6, 214-221. [CrossRef] 
144. Zhang, Y.; Huber, D.J.; Hu, M.; Jiang, G.; Gao, Z.; Xu, X.; Jiang, Y.; Zhang, Z. Delay of postharvest browning in litchi fruit by melatonin via the enhancing of antioxidative processes and oxidation repair. J. Agric. Food Chem. 2018, 66, 7475-7484. [CrossRef] [PubMed]

145. Arnao, M.B.; Hernández-Ruiz, J. Growth conditions determine different melatonin levels in Lupinus albus L. J. Pineal Res. 2013, 55, 149-155. [CrossRef] [PubMed]

146. Chen, Y.E.; Mao, J.-J.; Sun, L.-Q.; Huang, B.; Ding, C.-B.; Gu, Y.; Liao, J.-Q.; Hu, C.; Zhang, Z.W.; Yuan, S.; et al. Exogenous melatonin enhances salt stress tolerance in maize seedlings by improving antioxidant and photosynthetic capacity. Physiol. Plant. 2018, 164, 349-363. [CrossRef] [PubMed]

147. Pehlivan, N.; Guler, N.S. Protective effect of a natural ally on simultaneous mild heat and salt episodes in maize seedlings. Acta Physiol. Plant 2018, 40, 203. [CrossRef]

148. Erdal, S. Melatonin promotes plant growth by maintaining integration and coordination between carbon and nitrogen metabolisms. Plant Cell Rep. 2019, 38, 1001-1012. [CrossRef]

149. Ye, J.; Wang, S.; Deng, X.; Yin, L.; Xiong, B.; Wang, X. Melatonin increased maize (Zea mays L.) seedling drought tolerance by alleviating drought-induced photosynthetic inhibition and oxidative damage. Acta Physiol. Plant 2016, 38, 48. [CrossRef]

150. Fleta-Soriano, E.; Díaz, L.; Bonet, E.; Munné-Bosch, S. Melatonin may exert a protective role against drought stress in maize. J. Agron. Crop Sci. 2017, 203, 286-294. [CrossRef]

151. Huang, B.; Chen, Y.E.; Zhao, Y.Q.; Ding, C.B.; Liao, J.Q.; Hu, C.; Zhou, L.J.; Zhang, Z.W.; Yuan, S.; Yuan, M. Exogenous melatonin alleviates oxidative damages and protects Photosystem II in maize seedlings under drought stress. Front. Plant Sci. 2019, 10, 677. [CrossRef]

152. Li, Z.G.; Xu, Y.; Bai, L.K.; Zhang, S.Y.; Wang, Y. Melatonin enhances thermotolerance of maize seedlings (Zea mays L.) by modulating antioxidant defense, methylglyoxal detoxification, and osmoregulation systems. Protoplasma 2018, 256, 471-490. [CrossRef]

153. Okant, M.; Kaya, C. The role of endogenous nitric oxide in melatonin-improved tolerance to lead toxicity in maize plants. Environ. Sci. Pollut. Res. 2019, 26, 11864-11874. [CrossRef]

154. Zhao, H.; Su, T.; Huo, L.; Wei, H.; Jiang, Y.; Xu, L.; Ma, F. Unveiling the mechanism of melatonin impacts on maize seedling growth: Sugar metabolism as a case. J. Pineal Res. 2015, 59, 255-266. [CrossRef] [PubMed]

155. Kolodziejczyk, I.; Dzitko, K.; Szewczyk, R.; Posmyk, M.M. Exogenous melatonin expediently modifies proteome of maize (Zea mays L.) embryo during seed germination. Acta Physiol. Plant 2016, 38, 146. [CrossRef]

156. Su, X.; Xin, L.; Li, Z.; Zheng, H.; Mao, J.; Yang, Q. Physiology and transcriptome analyses reveal a protective effect of the radical scavenger melatonin in aging maize seeds. Free Radic. Res. 2018, 52, 1094-1109. [CrossRef] [PubMed]

157. Hodzic, E.; Balaban, M.; Suskalo, N.; Galijasevic, S.; Hasanagic, D.; Kukavica, B. Antioxidative response of Melissa officinalis L. and Valeriana officinalis L. leaves exposed to exogenous melatonin and excessive zinc and cadmium level. J. Serb. Chem. Soc. 2018, 84, 70. [CrossRef]

158. Szafranska, K.; Glinska, S.; Janas, K.M. Ameliorative effect of melatonin on meristematic cells of chilled and re-warmed Vigna radiata roots. Biol. Plant 2013, 57, 91-96. [CrossRef]

159. Gao, W.; Feng, Z.; Bai, Q.; He, J.; Wang, Y. Melatonin-mediated regulation of growth and antioxidant capacity in salt-tolerant naked oat under salt stress. Molecules 2019, 20, 1176. [CrossRef] [PubMed]

160. Gao, W.; Zhang, Y.; Feng, Z.; Bai, Q.; He, J.; Wang, Y. Effects of melatonin on antioxidant capacity in naked oat seedlings under drought stress. Molecules 2018, 23, 1580. [CrossRef]

161. Cao, S.; Song, C.; Shao, J.; Bian, K.; Chen, W.; Yang, Z. Exogenous melatonin treatment increases chilling tolerance and induces defense response in harvested peach fruit during cold storage. J. Agric. Food Chem. 2016, 64, 5215-5222. [CrossRef]

162. Gao, H.; Zhang, Z.K.; Chai, H.K.; Cheng, N.; Yang, Y.; Wang, D.N.; Yang, T.; Cao, W. Melatonin treatment delays postharvest senescence and regulates reactive oxygen species metabolism in peach fruit. Postharvest Biol. Technol. 2016, 118, 103-110. [CrossRef]

163. Liu, J.; Yue, R.; Si, M.; Wu, M.; Cong, L.; Zhai, R.; Yang, C.; Wang, Z.; Ma, F.; Xu, L. Effects of exogenous application of melatonin on quality and sugar metabolism in Zaosu pear fruit. J. Plant Growth Regul. 2019. [CrossRef]

164. Zhai, R.; Liu, J.; Liu, F.; Zhao, Y.; Liu, L.; Fang, C.; Wang, H.; Li, X.; Wang, Z.; Ma, F.; et al. Melatonin limited ethylene production, softening and reduced physiology disorder in pear (Pyrus communis L.) fruit during senescence. Postharvest Biol. Technol. 2018, 139, 38-46. [CrossRef] 
165. Liu, J.; Yang, J.; Zhang, H.; Cong, L.; Zhai, R.; Yang, C.; Wang, Z.; Ma, F.; Xu, L. Melatonin inhibits ethylene synthesis via nitric oxide regulation to delay postharvest senescence in pears. J. Agric. Food Chem. 2019, 67, 2279-2288. [CrossRef] [PubMed]

166. Kaya, C.; Higgs, D.; Ashraf, M.; Alyemeni, M.; Ahmad, P. Integrative roles of nitric oxide and hydrogen sulfide in melatonin-induced tolerance of pepper (Capsicum annuиm L.) plants to iron deficiency and salt stress alone or in combination. Physiol. Plant 2019. [CrossRef] [PubMed]

167. Korkmaz, A.; Karakas, A.; Kocacinar, F.; Cuci, Y. The effects of seed treatment with melatonin on germination and emergence performance of pepper seeds under chilling stress. J. Agric. Sci. 2017, 23, 167-176.

168. Sarafi, E.; Tsouvaltzis, P.; Chatzissavvidis, C.; Siomos, A.; Therios, I. Melatonin and resveratrol reverse the toxic effect of high boron (B) and modulate biochemical parameters in pepper plants (Capsicum annuum L.). Plant Physiol. Biochem. 2017, 112, 173-182. [CrossRef] [PubMed]

169. Szafranska, K.; Reiter, R.J.; Posmyk, M.M. Melatonin application to Pisum sativum L. seeds positively influences the function of the photosynthetic apparatus in growing seedlings during paraquat-induced oxidative stress. Front. Plant Sci. 2016, 7, 1663. [CrossRef]

170. Szafranska, K.; Reiter, R.J.; Posmyk, M.M. Melatonin improves the photosynthetic apparatus in pea leaves stressed by paraquat via chlorophyll breakdown regulation and its accelerated de novo synthesis. Front. Plant Sci. 2017, 8, 878. [CrossRef] [PubMed]

171. Tan, D.X.; Manchester, L.C.; Helton, P.; Reiter, R.J. Phytoremediative capacity of plants enriched with melatonin. Plant Sign. Behav. 2007, 2, 514-516. [CrossRef]

172. Bal, E. Physicochemical changes in Santa Rosa plum fruit treated with melatonin during cold storage. J. Food Meas. Charact. 2019, 13, 1713-1720. [CrossRef]

173. Jannatizadeh, A. Exogenous melatonin applying confers chilling tolerance in pomegranate fruit during cold storage. Sci. Hort. 2019, 246, 544-549. [CrossRef]

174. Ding, F.; Wang, G.; Zhang, S. Exogenous melatonin mitigates methyl viologen-triggered oxidative stress in poplar leaf. Molecules 2018, 23, 2852. [CrossRef] [PubMed]

175. Yu, Y.; Wang, A.; Li, X.; Kou, M.; Wang, W.; Chen, X.; Xu, T.; Zhu, M.; Ma, D.; Li, Z.; et al. Melatonin-stimulated triacylglycerol breakdown and energy turnover under salinity stress contributes to the maintenance of plasma membrane $\mathrm{H}^{+}$-ATPase activity and $\mathrm{K}^{+} / \mathrm{Na}^{+}$homeostasis in sweet potato. Front. Plant Sci. 2018, 9, 256. [CrossRef] [PubMed]

176. Zhang, S.; Zheng, X.; Reiter, R.J.; Feng, S.; Wang, Y.; Liu, S.; Jin, L.; Li, Z.; Datla, R.; Ren, M. Melatonin attenuates potato late blight by disrupting cell growth, stress tolerance, fungicide susceptibility and homeostasis of gene expression in Phytophthora infestans. Front. Plant Sci. 2017, 8, 1993. [CrossRef] [PubMed]

177. Jia, C.; Yu, X.; Zhang, M.; Liu, Z.; Zou, P.; Ma, J.; Xu, Y. Application of melatonin-enhanced tolerance to high-temperature stress in cherry radish (Raphanus sativus L. var. radculus pers). J. Plant Growth Regul. 2019. [CrossRef]

178. Zhao, G.; Zhao, Y.; Yu, X.; Felix, K.; Han, H.; Guan, R.; Wang, R.; Shen, W. Nitric oxide is required for melatonin-enhanced tolerance against salinity stress in rapeseed (Brassica napus L.) seedlings. Int. J. Mol. Sci. 2018, 19, 1912. [CrossRef] [PubMed]

179. Khan, M.N.; Zhang, J.; Luo, T.; Liu, J.; Rizwan, M.; Fahad, S.; Xu, Z.; Hu, L. Seed priming with melatonin coping drought stress in rapeseed by regulating reactive oxygen species detoxification: Antioxidant defense system, osmotic adjustment, stomatal traits and chloroplast ultrastructure perseveration. Ind. Crop Prod. 2019, 140, 111597. [CrossRef]

180. Han, Q.H.; Huang, B.; Ding, C.B.; Zhang, Z.W.; Chen, Y.E.; Hu, C.; Zhou, L.J.; Huang, Y.; Liao, J.Q.; Yuan, S.; et al. Effects of melatonin on anti-oxidative systems and Photosystem II in cold-stressed rice seedlings. Front. Plant Sci. 2017, 8, 785. [CrossRef] [PubMed]

181. Liang, C.; Zheng, G.; Li, W.; Wang, Y.; Hu, B.; Wang, H.; Wu, H.; Qian, Y.; Zhu, X.G.; Tan, D.X.; et al. Melatonin delays leaf senescence and enhances salt stress tolerance in rice. J. Pineal Res. 2015, 59, 91-101. [CrossRef]

182. Lee, K.; Back, K. Overexpression of rice serotonin $\mathrm{N}$-acetyltransferase 1 in transgenic rice plants confers resistance to cadmium and senescence and increases grain yield. J. Pineal Res. 2017, 62, e12392. [CrossRef]

183. Lee, H.Y.; Back, K. Cadmium disrupts subcellular organelles, including chloroplasts, resulting in melatonin induction in plants. Molecules 2017, 22, 1791. [CrossRef]

184. Chen, X.; Sun, C.; Laborda, P.; Zhao, Y.; Palmer, I.; Fu, Z.Q.; Qiu, J.; Liu, F. Melatonin treatment inhibits the growth of Xanthomonas oryzae pv. oryzae. Front. Microbiol. 2018, 9, 2280. [CrossRef] [PubMed] 
185. Wei, Y.; Zeng, H.; Hu, W.; Chen, L.; He, C.; Shi, H. Comparative transcriptional profiling of melatonin synthesis and catabolic genes indicates the possible role of melatonin in developmental and stress responses in rice. Front. Plant Sci. 2016, 7, 676. [CrossRef] [PubMed]

186. Park, S.; Back, K. Melatonin promotes seminal root elongation and root growth in transgenic rice after germination. J. Pineal Res. 2012, 53, 385-389. [CrossRef] [PubMed]

187. Liang, C.; Li, A.; Yu, H.; Li, W.; Liang, C.; Guo, S.; Zhang, R.; Chu, C. Melatonin regulates root architecture by modulating auxin response in rice. Front. Plant Sci. 2017, 8, 134. [CrossRef] [PubMed]

188. Wei, W.; Li, Q.; Chu, Y.-N.; Reiter, R.J.; Yu, X.M.; Zhu, D.H.; Zhang, W.K.; Ma, B.; Lin, Q.; Zhang, J.S.; et al. Melatonin enhances plant growth and abiotic stress tolerance in soybean plants. J. Exp. Bot. 2015, 66, 695-707. [CrossRef] [PubMed]

189. ZOU, J.N.; JIN, X.J.; WANG, M.X.Y. Effects of melatonin on photosynthesis and soybean seed growth during grain filling under drought stress. Photosynthetica 2019, 57, 512-520. [CrossRef]

190. Zhang, J.; Zeng, B.; Mao, Y.; Kong, X.; Wang, X.; Yang, Y.; Zhang, J.; Xu, J.; Rengel, Z.; Chen, Q. Melatonin alleviates aluminium toxicity through modulating antioxidative enzymes and enhancing organic acid anion exudation in soybean. Funct. Plant Biol. 2017, 44, 961-968. [CrossRef]

191. Moussa, H.R.; Algamal, S.M.A. Does Exogenous Application of Melatonin Ameliorate Boron Toxicity in Spinach Plants? Int. J. Veg. Sci. 2017, 23, 233-245. [CrossRef]

192. Aghdam, M.S.; Fard, J.R. Melatonin treatment attenuates postharvest decay and maintains nutritional quality of strawberry fruits (Fragaria x anannasa cv. Selva) by enhancing GABA shunt activity. Food Chem. 2017, 221, 1650-1657. [CrossRef]

193. Liu, C.; Zheng, H.; Sheng, K.; Liu, W.; Zheng, L. Effects of melatonin treatment on the postharvest quality of strawberry fruit. Postharvest Biol. Technol. 2018, 139, 47-55. [CrossRef]

194. Mukherjee, S.; David, A.; Yadav, S.; Baluska, F.; Bhatla, S.C. Salt stress-induced seedling growth inhibition coincides with differential distribution of serotonin and melatonin in sunflower seedling roots and cotyledons. Physiol. Plant 2014, 152, 714-728. [CrossRef] [PubMed]

195. Arora, D.; Bhatla, S.C. Melatonin and nitric oxide regulate sunflower seedling growth under salt stress accompanying differential expression of $\mathrm{Cu} / \mathrm{Zn}$ SOD and Mn SOD. Free Radic. Biol. Med. 2017, 106, 315-328. [CrossRef] [PubMed]

196. Kaur, H.; Bhatla, S.C. Melatonin and nitric oxide modulate glutathione content and glutathione reductase activity in sunflower seedling cotyledons accompanying salt stress. Nitric Oxide 2016, 59, 42-53. [CrossRef] [PubMed]

197. Li, J.; Yang, Y.; Sun, K.; Chen, Y.; Chen, X.; Li, X. Exogenous Melatonin Enhances Cold, Salt and Drought Stress Tolerance by Improving Antioxidant Defense in Tea Plant (Camellia sinensis (L.) O. Kuntze). Molecules 2019, 24, 1826. [CrossRef] [PubMed]

198. Li, J.; Arkorful, E.; Cheng, S.; Zhou, Q.; Li, H.; Chen, X.; Sun, K.; Li, X. Alleviation of cold damage by exogenous application of melatonin in vegetatively propagated tea plant (Camellia sinensis (L.) O. Kuntze). Sci. Hort. 2018, 238, 356-362. [CrossRef]

199. Zhao, L.; Chen, L.; Gu, P.; Zhan, X.; Zhang, Y.; Hou, C.; Wu, Z.; Wu, Y.F.; Wang, Q.C. Exogenous application of melatonin improves plant resistance to virus infection. Plant Pathol. 2019. [CrossRef]

200. Zhou, X.; Zhao, H.; Cao, K.; Hu, L.; Du, T.; Baluska, F.; Zou, Z. Beneficial roles of melatonin on redox regulation of photosynthetic electron transport and synthesis of D1 protein in tomato seedlings under salt stress. Front. Plant Sci. 2016, 7, 1823. [CrossRef]

201. Siddiqui, H.M.; Alamri, S.; Al-Khaishany, Y.M.; Khan, N.M.; Al-Amri, A.; Ali, M.H.; Alaraidh, A.I.; Alsahli, A.A. Exogenous melatonin counteracts $\mathrm{NaCl}$-induced damage by regulating the antioxidant system, proline and carbohydrates metabolism in tomato seedlings. Int. J. Mol. Sci. 2019, 20, 353. [CrossRef]

202. Yin, Z.; Lu, J.; Meng, S.; Liu, Y.; Mostafa, I.; Qi, M.; Li, T. Exogenous melatonin improves salt tolerance in tomato by regulating photosynthetic electron flux and the ascorbate-glutathione cycle. J. Plant Interact. 2019, 14, 453-463. [CrossRef]

203. Ding, F.; Liu, B.; Zhang, S. Exogenous melatonin ameliorates cold-induced damage in tomato plants. Sci. Hort. 2017, 219, 264-271. [CrossRef]

204. Ding, F.; Wang, M.; Liu, B.; Zhang, S. Exogenous melatonin mitigates photoinhibition by accelerating non-photochemical quenching in tomato seedlings exposed to moderate light during chilling. Front. Plant Sci. 2017, 8, 244. [CrossRef] [PubMed] 
205. Aghdam, M.S.; Luo, Z.; Jannatizadeh, A.; Sheikh-Assadi, M.; Sharafi, Y.; Farmani, B.; Fard, J.R.; Razavi, F. Employing exogenous melatonin applying confers chilling tolerance in tomato fruits by upregulating ZAT2/6/12 giving rise to promoting endogenous polyamines, proline, and nitric oxide accumulation by triggering arginine pathway activity. Food Chem. 2019, 275, 549-556. [CrossRef] [PubMed]

206. Xu, W.; Cai, S.Y.; Zhang, Y.; Wang, Y.; Ahammed, G.J.; Xia, X.J.; Shi, K.; Zhou, Y.H.; Yu, J.Q.; Reiter, R.J.; et al. Melatonin enhances thermotolerance by promoting cellular protein protection in tomato plants. J. Pineal Res. 2016, 61, 457-469. [CrossRef] [PubMed]

207. Ahammed, G.J.; Xu, W.; Liu, A.; Chen, S. Endogenous melatonin deficiency aggravates high temperature-induced oxidative stress in Solanum lycopersicum L. Environ. Exp. Bot. 2019, 161, 303-311. [CrossRef]

208. Qi, Z.Y.; Wang, K.X.; Yan, M.Y.; Kanwar, K.M.; Li, D.Y.; Wijaya, L.; Alyemeni, N.M.; Ahmad, P.; Zhou, J. Melatonin alleviates high temperature-induced pollen abortion in Solanum lycopersicum. Molecules 2018, 23, 386. [CrossRef] [PubMed]

209. Hasan, M.; Ahammed, G.J.; Yin, L.; Shi, K.; Xia, X.; Zhou, Y.; Yu, J.; Zhou, J. Melatonin mitigates cadmium phytotoxicity through modulation of phytochelatins biosynthesis, vacuolar sequestration and antioxidant potential in Solanum lycopersicum L. Front. Plant Sci. 2015, 6, 601. [CrossRef] [PubMed]

210. Cai, S.Y.; Zhang, Y.; Xu, Y.P.; Qi, Z.Y.; Li, M.Q.; Ahammed, G.J.; Xia, X.J.; Shi, K.; Zhou, Y.H.; Reiter, R.J.; et al. HsfA1a upregulates melatonin biosynthesis to confer cadmium tolerance in tomato plants. J. Pineal Res. 2017, 62, e12387. [CrossRef]

211. Li, M.Q.; Hasan, M.; Li, C.X.; Ahammed, G.J.; Xia, X.J.; Shi, K.; Zhou, Y.H.; Reiter, R.J.; Yu, J.Q.; Xu, M.X.; et al. Melatonin mediates selenium-induced tolerance to cadmium stress in tomato plants. J. Pineal Res. 2016, 61, 291-302. [CrossRef]

212. Liu, N.; Jin, Z.; Wang, S.; Gong, B.; Wen, D.; Wang, X.; Wei, M.; Shi, Q. Sodic alkaline stress mitigation with exogenous melatonin involves reactive oxygen metabolism and ion homeostasis in tomato. Sci. Hort. 2015, 181, 18-25. [CrossRef]

213. Debnath, B.; Hussain, M.; Irshad, M.; Mitra, S.; Li, M.; Liu, S.; Qiu, D. Exogenous melatonin mitigates acid rain stress to tomato plants through modulation of leaf ultrastructure, photosynthesis and antioxidant potential. Molecules 2018, 23, 388. [CrossRef]

214. Ding, F.; Wang, G.; Wang, M.; Zhang, S. Exogenous melatonin improves tolerance to water deficit by promoting cuticle formation in tomato plants. Molecules 2018, 23, 1605. [CrossRef] [PubMed]

215. Karaca, P.; Cekic, F.O. Exogenous melatonin-stimulated defense responses in tomato plants treated with polyethylene glycol. Int. J. Veg. Sci. 2019. [CrossRef]

216. Hasn, M.; Liu, C.X.; Pan, Y.T.; Ahammed, G.J.; Qi, Z.Y.; Zhou, J. Melatonin alleviates low-sulfur stress by promoting sulfur homeostasis in tomato plants. Sci. Rep. 2018, 8, 10182. [CrossRef] [PubMed]

217. Wen, D.; Gong, B.; Sun, S.; Liu, S.; Wang, X.; Wei, M.; Yang, F.; Li, Y.; Shi, Q. Promoting roles of melatonin in adventitious root development of Solanum lycopersicum L. by regulating auxin and nitric oxide signaling. Front. Plant Sci. 2016, 7, 718. [CrossRef] [PubMed]

218. Liu, J.; Zhang, R.; Sun, Y.; Liu, Z.; Jin, W.; Sun, Y. The beneficial effects of exogenous melatonin on tomato fruit properties. Sci. Hort. 2016, 207, 14-20. [CrossRef]

219. Sun, Q.; Zhang, N.; Wang, J.; Cao, Y.; Li, X.; Zhang, H.; Zhang, L.; Tan, D.X.; Guo, Y.D. A label-free differential proteomics analysis reveals the effect of melatonin on promoting fruit ripening and anthocyanin accumulation upon postharvest in tomato. J. Pineal Res. 2016, 61, 138-153. [CrossRef] [PubMed]

220. Li, H.; Dong, Y.; Chang, J.; He, J.; Chen, H.; Liu, Q.; Wei, C.; Ma, J.; Zhang, Y.; Yang, J.; et al. High-throughput microRNA and mRNA sequencing reveals that microRNAs may be involved in melatonin-mediated cold tolerance in Citrullus lanatus L. Front. Plant Sci. 2016, 7, 1231. [CrossRef] [PubMed]

221. Li, H.; Chang, J.; Chen, H.; Wang, Z.; Gu, X.; Wei, C.; Zhang, Y.; Ma, J.; Yang, J.; Zhang, X. Exogenous melatonin confers salt stress tolerance to watermelon by improving photosynthesis and redox homeostasis. Front. Plant Sci. 2017, 8, 295. [CrossRef]

222. Nawaz, M.A.; Jiao, Y.; Chen, C.; Shireen, F.; Zheng, Z.; Imtiaz, M.; Bie, Z.; Huang, Y. Melatonin pretreatment improves vanadium stress tolerance of watermelon seedlings by reducing vanadium concentration in the leaves and regulating melatonin biosynthesis and antioxidant-related gene expression. J. Plant Physiol. 2018, 220, 115-127. [CrossRef] 
223. Turk, H.; Erdal, S.; Genisel, M.; Atici, O.; Demir, Y.; Yanmis, D. The regulatory effect of melatonin on physiological, biochemical and molecular parameters in cold-stressed wheat seedlings. Plant Growth Regul. 2014, 74, 139-152. [CrossRef]

224. Li, X.; Brestic, M.; Tan, D.X.; Zivcak, M.; Zhu, X.; Liu, S.; Song, F.; Reiter, R.J.; Liu, F. Melatonin alleviates low PS I-limited carbon assimilation under elevated $\mathrm{CO}_{2}$ and enhances the cold tolerance of offspring in chlorophyll b-deficient mutant wheat. J. Pineal Res. 2018, 64, e12453. [CrossRef] [PubMed]

225. Sun, L.; Li, X.; Wang, Z.; Sun, Z.; Zhu, X.; Liu, S.; Song, F.; Liu, F.; Wang, Y. Cold priming induced tolerance to subsequent low temperature stress is enhanced by melatonin application during recovery in wheat. Molecules 2018, 23, 1091. [CrossRef] [PubMed]

226. Ke, Q.; Ye, J.; Wang, B.; Ren, J.; Yin, L.; Deng, X.P.; Shiwen, W. Melatonin mitigates salt stress in wheat seedlings by modulating polyamine metabolism. Front. Plant Sci. 2018, 9, 914. [CrossRef] [PubMed]

227. Zafar, S.; Hasnain, Z.; Anwar, S.; Perveen, S.; Iqbal, N.; Noman, A.; Ali, M. Influence of melatonin on antioxidant defense system and yield of wheat (Triticum aestivum L.) genotypes under saline condition. Pak. J. Bot. 2019, 51, 1987-1994. [CrossRef]

228. Cui, G.; Zhao, X.; Liu, S.; Sun, F.; Zhang, C.; Xi, Y. Beneficial effects of melatonin in overcoming drought stress in wheat seedlings. Plant Physiol. Biochem. 2017, 118, 138-149. [CrossRef] [PubMed]

229. Ni, J.; Wang, Q.; Shah, A.F.; Liu, W.; Wang, D.; Huang, S.; Fu, S.; Wu, L. Exogenous melatonin confers cadmium tolerance by counterbalancing the hydrogen peroxide homeostasis in wheat seedlings. Molecules 2018, 23, 799. [CrossRef] [PubMed]

230. Kaya, C.; Okant, M.; Ugurlar, F.; Alyemeni, M.N.; Ashraf, M.; Ahmad, P. Melatonin-mediated nitric oxide improves tolerance to cadmium toxicity by reducing oxidative stress in wheat plants. Chemosphere 2019, 225, 627-638. [CrossRef]

231. Zuo, Z.; Sun, L.; Wang, T.; Miao, P.; Zhu, X.; Liu, S.; Song, F.; Mao, H.; Li, X. Melatonin improves the photosynthetic carbon assimilation and antioxidant capacity in wheat exposed to nano-ZnO stress. Molecules 2017, 22, 1727. [CrossRef]

232. Qiao, Y.; Yin, L.; Wang, B.; Ke, Q.; Deng, X.; Wang, S. Melatonin promotes plant growth by increasing nitrogen uptake and assimilation under nitrogen deficient condition in winter wheat. Plant Physiol. Biochem. 2019, 139, 342-349. [CrossRef]

233. Hoffman, R.A.; Reiter, R.J. Pineal gland: Influence on gonads of male hamsters. Science 1965, 148, $1609-1611$. [CrossRef]

234. Choi, D. Effects of dietary supplement containing melatonin on reproductive activity in male golden hamsters. Dev. Reprod. 2019, 23, 101-110. [CrossRef] [PubMed]

235. deNicolo, G.; Morris, S.T.; Kenyon, P.R.; Morel, P.C.H.; Parkinson, T.J. Melatonin-improved reproductive performance in sheep bred out of season. Anim. Reprod. Sci. 2008, 109, 124-133. [CrossRef] [PubMed]

236. Yakhin, O.I.; Lubyanov, A.A.; Yakhin, I.A.; Brown, P.H. Biostimulants in Plant Science: A Global Perspective. Front. Plant Sci. 2017, 7, 2049. [CrossRef] [PubMed]

237. Hernández-Ruiz, J.; Arnao, M.B. Phytomelatonin, an interesting tool for agricultural crops. Focus Sci. 2016, 2, 1-7. [CrossRef]

238. Arnao, M.B.; Hernández-Ruiz, J. The potential of phytomelatonin as a nutraceutical. Molecules 2018, $23,238$. [CrossRef] [PubMed]

239. Arnao, M.B.; Hernández-Ruiz, J. Phytomelatonin, natural melatonin from plants as a novel dietary supplement: Sources, activities and world market. J. Funct. Foods 2018, 48, 37-42. [CrossRef]

(C) 2019 by the authors. Licensee MDPI, Basel, Switzerland. This article is an open access article distributed under the terms and conditions of the Creative Commons Attribution (CC BY) license (http://creativecommons.org/licenses/by/4.0/). 